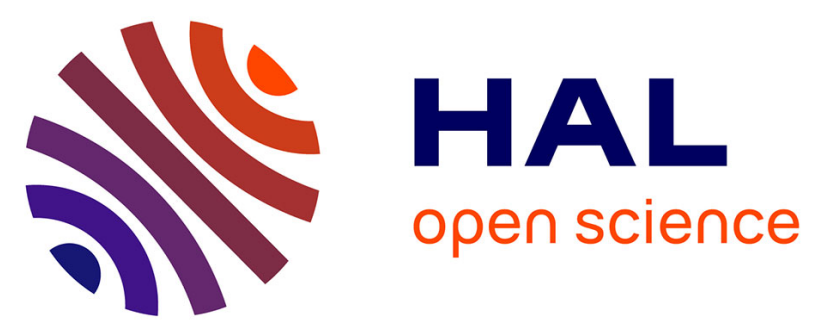

\title{
Distribution and diagenesis of trace metals in marine sediments of a coastal Mediterranean area: St-Georges Bay (Lebanon)
}

Amonda El Houssainy, Carine Abi-Ghanem, Duc Huy Dang, Céline Mahfouz, Dario Omanović, Gaby Khalaf, Stéphane Mounier, Cédric Garnier

\section{To cite this version:}

Amonda El Houssainy, Carine Abi-Ghanem, Duc Huy Dang, Céline Mahfouz, Dario Omanović, et al.. Distribution and diagenesis of trace metals in marine sediments of a coastal Mediterranean area: St-Georges Bay (Lebanon). Marine Pollution Bulletin, 2020, 155, pp.111066. 10.1016/j.marpolbul.2020.111066 . hal-02561935

\section{HAL Id: hal-02561935 \\ https://hal.science/hal-02561935}

Submitted on 4 May 2020

HAL is a multi-disciplinary open access archive for the deposit and dissemination of scientific research documents, whether they are published or not. The documents may come from teaching and research institutions in France or abroad, or from public or private research centers.
L'archive ouverte pluridisciplinaire HAL, est destinée au dépôt et à la diffusion de documents scientifiques de niveau recherche, publiés ou non, émanant des établissements d'enseignement et de recherche français ou étrangers, des laboratoires publics ou privés. 


\title{
Distribution and diagenesis of trace metals in marine sediments of a coastal Mediterranean area: St-Georges Bay (Lebanon)
}

\author{
Amonda El HOUSSAINY ${ }^{\text {a, }}$, Carine ABI-GHANEM ${ }^{\text {c }}$, Duc Huy DANG ${ }^{\text {d }}$, Céline MAHFOUZ ${ }^{\text {b }}$, \\ Dario OMANOVIĆ $^{\mathrm{e}}$, Gaby KHALAF $^{\mathrm{b}}$, Stéphane MOUNIER ${ }^{\mathrm{a}}$, Cédric GARNIER $^{\mathrm{a}, \dagger}$
}

a. Univ Toulon, Aix Marseille Univ., CNRS/INSU, IRD, MIO UM 110, Mediterranean Institute of Oceanography, La Garde, France. amonda.houssainy@gmail.com, mounier@univ-tln.fr

b. CNRS, National Centre for Marine Sciences, P.O.Box 534, Batroun, Lebanon. bihar@cnrs.edu.lb, celine.mahfouz@gmail.com

c. Lebanese University Faculty of Sciences III, Tripoli, Lebanon. carine.a.ghanem@hotmail.fr

d. Trent School of the Environment and Chemistry Department, Trent University, 1600 West Bank Drive, Peterborough, ON Canada, K9L 0G2.huydang@trentu.ca

e. Ruđer Bošković Institute, Division for marine and environmental research, Bijenička cesta 54, 10000 Zagreb, Croatia.omanovic@irb.hr

\begin{abstract}
:
St-Georges Bay (Lebanon) is an open bay, to the Mediterranean Sea and it is exposed to numerous anthropogenic activities such as industrial effluents, non-treated wastewater discharge and maritime activities leading an increasing chemical contamination especially with trace metals. Contamination with trace metals $(\mathrm{Cu}, \mathrm{Cd}, \mathrm{Co}, \mathrm{Pb}, \mathrm{As}, \mathrm{Ag}$ and $\mathrm{Hg})$ and the influence of early diagenesis on their distribution are studied on both sediments and waters transect. For this purpose, sediment cores were collected, then treated under inert atmosphere to retrieve pore waters and solid fraction. The area appeared to be seriously impacted by the transport through Beirut River and/or by direct inputs, and the recent landscaping done with dumpsite material. The sediments showed a significant level of contamination. Element mobility was studied by selective extraction on sediments. The mobility of the studied trace elements from solid fraction to pore waters is controlled by Fe/Mn cycle and organic matter.
\end{abstract}

Keywords: Mediterranean, trace metals, early diagenesis, sediments, pore waters.

\section{Introduction}

Numerous anthropogenic activities such as maritime traffic, harbor activities, discharge of wastewater, solid waste disposal or industrial effluents in coastal areas had negatively impact on the surrounded 
environment, seriously releasing several pollutants such as trace metals as point sources in the surrounding environment. Industrial activities (e.g. tannery, foundry or paper processing) can release trace metals wastewaters contaminating the coastal areas and causing a massive ecological impact on water organisms (Qian et al., 2015). Trace metals are also introduced into estuarine and coastal zones from nonpoint sources through aeolian and/or alluvial processes for example atmospheric transport, underground waters, rivers, run-off and ocean outfalls (Chester, 1990; Lu et al., 2014). Once in coastal areas, trace metals are distributed in different phases such as aqueous, colloids or suspended matter and sedimentary phases. Trace metals are non-degradable contaminants; they can be adsorbed onto settling particles, which turn the sediment into the ultimate sink but also into an essential source of contaminants for the surrounding ecosystem due to natural or anthropogenic disturbance (Pan and Wang, 2012; Rigaud et al., 2013; Shaw et al., 1990; Singh et al., 2005). In the sediments, trace metals can remain adsorbed to clay surfaces or Fe/Mn (oxy)hydroxides, complexed with organic matter (OM) or incorporate in amorphous materials (Lu et al., 2014; Peng et al., 2009). However, high concentration of trace metals in sediments reflect the degree of contamination but not the toxicity for the aquatic systems, which is related to chemical speciation. This contamination can later affect directly aquatic organisms, presenting a longterm accumulative effect (Lu et al., 2014; Pan and Wang, 2012). Hence, many biogeochemical processes occurring in the estuarine-coastal mixing area may affect the solid-liquid repartitioning of these metals, and their input to the water column such as diffusive flux, resuspension of sediments and early diagenesis (Elbaz-Poulichet, 2005; Rigaud et al., 2013; Scholz and Neumann, 2007). Early diagenesis is a set of chemicals (e.g. sorption, dissolution/precipitation), biologicals and physicals (e.g. sedimentation) processes taking place in the sediments and controlled by benthic life and bacterial activities. These processes control the trace metal mobility from sediment to surface waters and allow understanding their distribution in the sediments (Elbaz-Poulichet, 2005; Tankere-Muller et al., 2007). The mineralization of organic matter is the driving force of early diagenesis where the organic matter is degraded close to water/sediment interface (Chester, 1990).

Diagenetic primary processes start with aerobic oxidation of OM by using dissolved oxygen from the overlying or interstitial waters as an oxidant near the sediment-water interface (SWI). When oxygen is completely consumed or falls to very low levels, $\mathrm{OM}$ decomposition can occur by using sequentially $\mathrm{NO}_{3}{ }^{-}$ , Mn (oxy)hydroxides $\left(\mathrm{MnO}_{\mathrm{x}}\right), \mathrm{Fe}$ (oxy)hydroxides $\left(\mathrm{Fe}_{2} \mathrm{O}_{3}\right.$ or $\left.\mathrm{FeOOH}\right)$ as electrons acceptors (Chester, 1990; Froelich et al., 1979). The reductive dissolution of $\mathrm{Mn} / \mathrm{Fe}$ (oxy)hydroxide releases in pore waters trace metals previously bound/incorporated to the settled oxides. Sulfate reduction occurs in the sulfidic anaerobic areas where $\mathrm{SO}_{4}{ }^{2-}$ is used as electrons acceptors. In the contrary, sulfate reduction to sulfide could sequestrate dissolved trace metals in sulfide precipitates (Burgos et al., 2018; Froelich et al., 1979; 
Hyacinthe et al., 2001; Lesven et al., 2008). In anaerobic conditions, following sulfate reduction, the last reaction, methanogenesis, occurs where biogenic dissolved methane can be formed (Burdige and Komada, 2011; Chester, 1990; Froelich et al., 1979). These primary redox reactions are vertically stratified depending on their energy yield and the reduced species produced such as $\mathrm{NH}_{4}{ }^{+}, \mathrm{Mn}^{2+}, \mathrm{Fe}^{2+}, \mathrm{HS}^{-}$ , $\mathrm{CH}_{4}$ take part in secondary redox reactions in diagenetic reactions (Canavan et al., 2006). Moreover, primary and secondary redox reactions divide sediments into different zones of redox conditions (e.g. oxic, sub-oxic, anoxic and sulfidic) (Canavan et al., 2006; Chester, 1990; Rigaud, 2011). However, this order can be disturbed due to the presence of a set of microenvironments with redox condition controlled by different bacterial populations (Achard, 2013). Several studies related to trace metal contamination in marine sediments were conducted in the Mediterranean Sea (Álvarez-Iglesias et al., 2006; Cossa et al., 2014) and along the Lebanese coasts (Abi-Ghanem et al., 2009; Nakhle, 2004; Nassif, 2010) (Table1). The Lebanese studies that focused on solid phase contamination, have shown that Dora area in Beirut is the most contaminated zone of Lebanon. However, there is a lack of study aiming at shedding light on the impacts of diagenetic process on metal-mobilization in pore waters and at identifying the link between sedimentary accumulation and water column transport processes. Therefore, the aim of this study is: 1) to assess the contamination status of the Lebanese coastal sediments of St-Georges Bay - Dora; 2) to study the influence of early diagenesis on trace metal distribution and their distribution between the solid phase and pore waters in the studied sites. For this, diagenetic tracers, organic carbon and a series of minor/major/trace elements ( $\mathrm{Al}, \mathrm{Ag}, \mathrm{As}, \mathrm{Cd}, \mathrm{Co}, \mathrm{Cu}, \mathrm{Fe}, \mathrm{Hg}, \mathrm{Mn}, \mathrm{Pb}$ and $\mathrm{Rb}$ ) were measured in pore water and solid fraction (sediments) in three Dora bay sites.

\section{Area of study}

St-Georges Bay is located in the coastal area of Beirut-Lebanon (Eastern Mediterranean Sea). This bay is subjected to pollution pressures and a variety of runoff water regimes between a rainy winter-spring and dry summer seasons. This bay suffers from serious environmental pollution issues due to fuels containers, non-treated industrial effluents, maritime traffic and the former massive solid waste dump 'Dora Dumpsite" in direct contact with water. The dumpsite has been releasing pollutants to water for 20 years until it was closed in 1998 (Nakhle, 2004). Recently, a new land (green area, Figure 1) was built from the solid waste of the dumpsite (blue area, Figure 1). In the north of the bay, the Beirut River flows into the bay. It takes its source in Mount of Lebanon at an altitude of $1,890 \mathrm{~m}$. It is a karstic and seasonal river; consequently, monthly flow rate varies between 0.01 and $16 \mathrm{~m}^{3} / \mathrm{s}$, in addition, non-treated domestic and industrial wastewater discharged are transported into the Beirut River. These sewage waters represent almost the entire flow of the water transported by the river during the dry season (Maatouk, 2015). 


\section{Materials and methods}

\subsection{Sampling}

Sediment sampling campaigns were carried out in September 2016 and July 2017 at St-Georges BayLebanon. Samples were collected at three stations "D0" in front of the estuary of Beirut River, "D1", and "D2" in front of the dumpsite and an industrial effluent (Figure 1). For each sampling point, seawater was collected in FEP bottles at 0.5, 2.5, 5 and $6 \mathrm{~m}$ from the surface. In addition, three sediment cores were collected using 10-cm diameter and 1-m long Plexiglas ${ }^{\circledR}$ tube at each station with the support of the scientific boat "CANA" and its divers (Figure 1). The first sediment core (pre-drilled holes each $2 \mathrm{~cm}$ ) was collected to measure $\mathrm{pH}$ and redox potential (ORP). In parallel, a second core was stabilized for $24 \mathrm{~h}$ to collect supernatant water (SW), then SW was simultaneous recovered at 2, 5 and $15 \mathrm{~cm}$ from sea water interface (SWI) and filtered $(0.2 \mu \mathrm{m}$, cellulose nitrate, Sartorius). The third core was sliced with a $2 \mathrm{~cm}$ resolution from top to bottom under an inert atmosphere $\left(\mathrm{N}_{2}\right)$ to preserve redox conditions. The collected sediments were then centrifuged (for $15 \mathrm{~min}, 3,077 \mathrm{~g}, 20^{\circ} \mathrm{C}$ ). Then, pore waters were collected also under inert atmosphere, filtered $(0.2 \mu \mathrm{m}$, cellulose nitrate, Sartorius). The solid fraction was homogenized and deep-frozen, then freeze-dried $\left(-18{ }^{\circ} \mathrm{C}\right), 2 \mathrm{~mm}$ sieved, crushed and kept deep-frozen until analysis. 


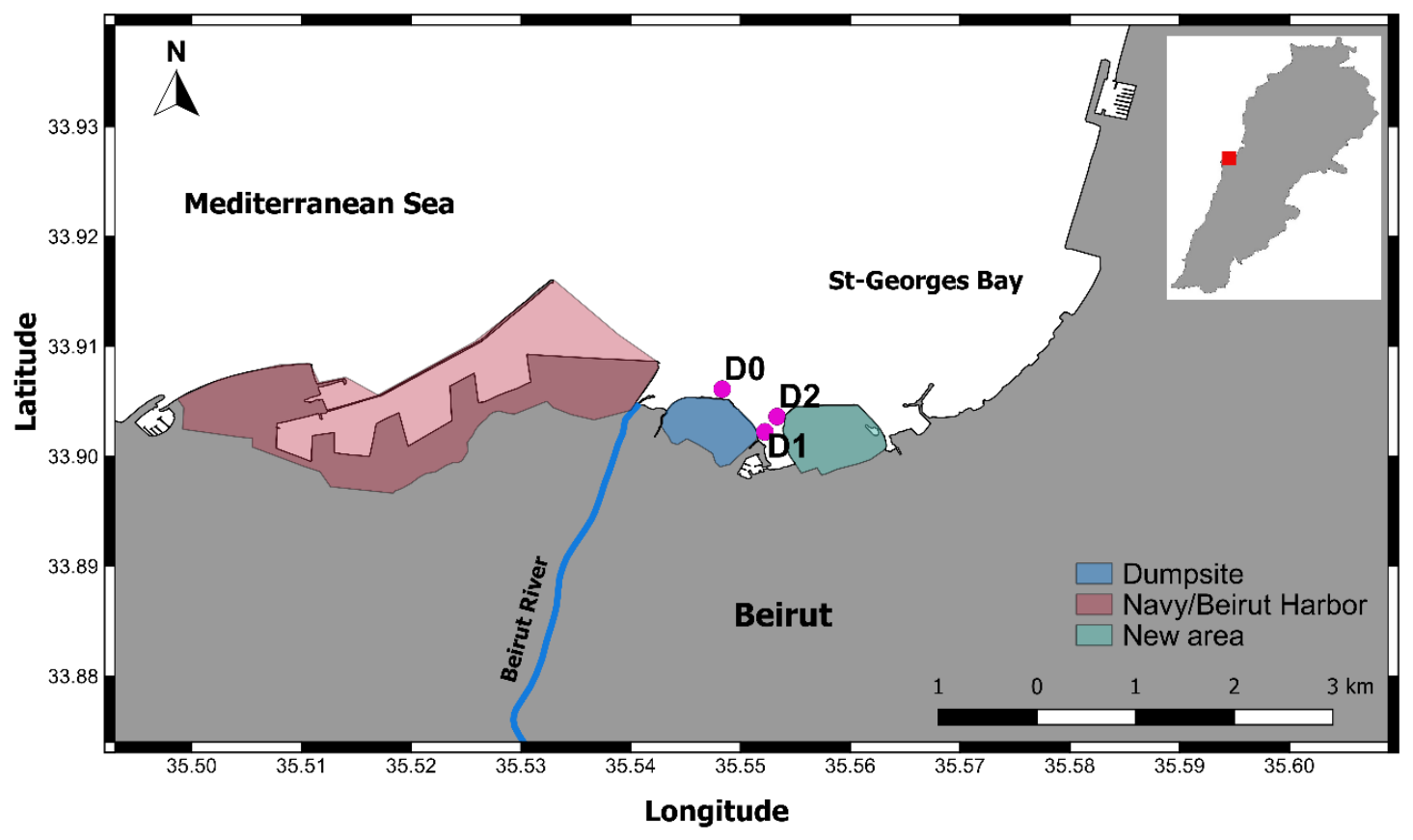

Figure 1: Map of the studied area and location of the sampled sediment cores DO, D1 and D2.

\subsection{Sediment analysis}

Total and particulate organic carbon (TC/POC) and total sulfur (TS) in sediments were analyzed using a TOC-V $\mathrm{V}_{\mathrm{CHS}}$ analyzer (Shimadzu). The organic carbon content was measured after treating sediments with $6 \mathrm{M} \mathrm{HCl}$. TS was measured after mixing $\sim 3 \mathrm{mg}$ of freeze dried sediments with $\sim 1.5 \mathrm{mg}$ of vanadium pentoxide $\mathrm{V}_{2} \mathrm{O}_{5}$ (Thermo Fisher scientific). For both measurements of carbon and sulfur, two reference soils were used Soil Reference material NC and NCS (Thermo Fisher scientific). Mineralogy and granulometry of studied sediment were measured by DRX (Panalytical X'Pert PRO) and Laser (Malvem hydro 2000G) respectively. Elements concentrations were determined after an aqua regia and microwave assisted digestion of sediments. The obtained solutions were filtered $(0.2 \mu \mathrm{m}$, cellulose nitrate, Sartorius) and diluted for analysis. Concentrations of minor/trace elements were measured by High Resolution Inductively Coupled Plasma - Mass Spectrometer (HR - ICP/MS, Element 2, Finnigan) and validated by using CASS-5 (Nearshore seawater certified reference material, National Research Council of Canada NRC) and SLRS-5 (River water certified reference material - NRC) for water samples and PACS2 (NRC) for sediments. Hg concentrations were measured using an Advanced Mercury Analyzer AMA-254 on $\sim 5$ to $30 \mathrm{mg}$ of sediments without pre-treatment and MESS-3 (NRC) was used as a certified reference material. For all measurement, the analytical recovery was within $10 \%$ comparing to certified concentration. 
In order to explore the behavior and the distribution of trace metals (TM), "Spearman" correlation matrices and PCA were performed by using toolboxes within R programing environment for all the data set. Selective extractions with $\mathrm{HCl} 1 \mathrm{M}, \mathrm{NaOH} 0.1 \mathrm{M}$ and ascorbate $(\mathrm{pH}=8.2)$ solutions were performed on freeze-dried sediments of each cores. Ascorbate extraction was performed to selectively extract trace elements associated to easily reducible iron (oxy)hydroxides (Haese et al., 2000). $\mathrm{HCl}$ extraction was applied to determine elements associated to carbonates, iron oxides and iron phosphate as well as acid volatile sulfide AVS (Haese et al., 2000; Leleyter and Baraud, 2005). Alkaline extraction is performed to extract a significant fraction of trace elements associated to organic matter (Ho et al., 2012). The same protocol was used for the three extractions: a solid/liquid ratio $300 \mathrm{mg} / 10 \mathrm{~mL}$ of samples were prepared than head-over-head shaken for $24 \mathrm{~h}$, centrifuged (3,077 g, $15 \mathrm{~min})$, filtered through $0.2 \mu \mathrm{m}$ syringe filter for the whole layers at each sediment cores. In results and discussion part, we will present and discuss only the mean percentage of extracted elements.

\subsection{Enrichment factors (EF)}

To explain the origin of trace elements in sediment and show the influence of anthropogenic activities, enrichment factors (EF) were calculated by comparing trace elements concentrations to the geochemical background of the studying area, using the following equation:

$$
E F=\frac{\left(\frac{M e}{X}\right) \text { sample }}{\left(\frac{M e}{X}\right) \text { background }}
$$

Where used $\mathrm{X}$ is Al. Since there is no accepted pollution ranking by authors five categories system of enrichment are proposed by Sutherland, 2000:

$\mathrm{EF}<2$ : absence to low enrichment; crustal origin

$2<\mathrm{EF}<5$ : moderate enrichment

$5<\mathrm{EF}<20$ : Significant enriched; non - crustal source

$20<\mathrm{EF}<40$ : Highly enriched

$\mathrm{EF}>40$ : Extremely enriched 
Table 1 Range and mean values of trace elements in sediments core from St-George Bay - Dora - Lebanon. Average of trace elements concentrations found in sediment

\begin{tabular}{|c|c|c|c|c|c|c|c|c|c|}
\hline & & $\begin{array}{c}\text { Ag } \\
\left(\mu \mathrm{g} \cdot \mathrm{g}^{1}\right)\end{array}$ & $\begin{array}{c}\text { Cd } \\
\left(\mu \mathrm{g} . \mathrm{g}^{1}\right)\end{array}$ & $\begin{array}{c}\text { Pb } \\
\left(\mu \mathrm{g} \cdot \mathrm{g}^{1}\right)\end{array}$ & $\begin{array}{c}\mathrm{Cr} \\
\left(\mu \mathrm{g} . \mathrm{g}^{1}\right)\end{array}$ & $\begin{array}{c}\text { Co } \\
\left(\mu \mathrm{g} \cdot \mathbf{g}^{1}\right)\end{array}$ & $\begin{array}{c}\mathrm{Cu} \\
\left(\mu \mathrm{g} . \mathrm{g}^{1}\right)\end{array}$ & $\begin{array}{c}\text { As } \\
\left(\mu \mathrm{g} . \mathrm{g}^{1}\right)\end{array}$ & $\begin{array}{c}\text { Hg } \\
\left(\mu \mathrm{g} . \mathrm{g}^{1}\right)\end{array}$ \\
\hline \multirow{3}{*}{ D0 $(8)^{a}$} & Range & $0.6-0.9$ & $\begin{array}{c}0.4- \\
0.5\end{array}$ & $\begin{array}{c}25.1- \\
44.3\end{array}$ & $\begin{array}{l}86.9- \\
107.7\end{array}$ & $\begin{array}{c}12.6- \\
16.3\end{array}$ & $\begin{array}{c}34.8- \\
53.1\end{array}$ & $6.5-9.8$ & $\begin{array}{c}0.1- \\
0.1\end{array}$ \\
\hline & & & & & & & & & \\
\hline & Average & $0.7 \pm 0.7$ & $\begin{array}{l}0.4 \pm \\
0.03\end{array}$ & $\begin{array}{c}35.2 \pm \\
5.5\end{array}$ & $\begin{array}{c}99.5 \pm \\
7.0\end{array}$ & $\begin{array}{c}14.9 \pm \\
1.5\end{array}$ & $\begin{array}{c}47.5 \pm \\
10.8\end{array}$ & $\begin{array}{c}8.2 \pm \\
1.2\end{array}$ & $\begin{array}{l}0.1 \pm \\
0.03\end{array}$ \\
\hline \multirow{2}{*}{ D1 (15) } & Range & $1.0-2.6$ & $\begin{array}{c}0.5- \\
1.1\end{array}$ & $\begin{array}{l}58.7- \\
140.0\end{array}$ & $\begin{array}{c}126.2- \\
298.8\end{array}$ & $\begin{array}{c}14.5- \\
26.0\end{array}$ & $\begin{array}{l}73.2- \\
142.0\end{array}$ & $\begin{array}{c}10.0- \\
16.4\end{array}$ & $\begin{array}{c}0.1- \\
0.3\end{array}$ \\
\hline & Average & $1.5 \pm 0.5$ & $\begin{array}{c}0.7 \pm \\
0.2\end{array}$ & $\begin{array}{c}92.1 \pm \\
18.6\end{array}$ & $\begin{array}{c}189.2 \pm \\
52.5\end{array}$ & $\begin{array}{c}19.78 \pm \\
3.5\end{array}$ & $\begin{array}{c}96.7 \pm \\
16\end{array}$ & $\begin{array}{c}12.9 \pm \\
2.2\end{array}$ & $\begin{array}{l}0.2 \pm \\
0.05\end{array}$ \\
\hline \multirow[b]{2}{*}{ D2 (15) } & Range & $1.5-5.6$ & $\begin{array}{c}0.6- \\
0.9\end{array}$ & $\begin{array}{l}64.3- \\
376.1\end{array}$ & $\begin{array}{c}158.3- \\
230.9\end{array}$ & $\begin{array}{c}16.4- \\
23.6\end{array}$ & $\begin{array}{l}66.6- \\
201.4\end{array}$ & $\begin{array}{c}13.1- \\
18.6\end{array}$ & $\begin{array}{c}0.2- \\
0.7\end{array}$ \\
\hline & Average & $2.9 \pm 1.3$ & $\begin{array}{c}0.7 \pm \\
0.3\end{array}$ & $\begin{array}{c}118.4 \pm \\
75.9\end{array}$ & $\begin{array}{c}182.6 \pm \\
19.3\end{array}$ & $\begin{array}{c}18.3 \pm \\
2.2\end{array}$ & $\begin{array}{c}93.2 \pm \\
32.1\end{array}$ & $\begin{array}{c}15.3 \pm \\
1.89\end{array}$ & $\begin{array}{c}0.4 \pm \\
0.1\end{array}$ \\
\hline $\begin{array}{c}\text { Aguada Bay - } \\
\text { India(Prajith et } \\
\text { al., 2016) }\end{array}$ & Average & - & - & $\begin{array}{c}10.7 \pm \\
2.91\end{array}$ & $\begin{array}{c}218 \pm \\
115\end{array}$ & $\begin{array}{c}20.5 \pm \\
4.85\end{array}$ & $\begin{array}{c}65.9 \pm \\
39\end{array}$ & - & - \\
\hline $\begin{array}{c}\text { San Simón Bay } \\
\text { - Spain(Álvarez- } \\
\text { Iglesias et al., } \\
\text { 2006) }\end{array}$ & Average & - & - & $\begin{array}{c}46.4 \pm \\
27.7\end{array}$ & $\begin{array}{c}79.5 \pm \\
24.8\end{array}$ & $\begin{array}{c}6.0 \pm \\
2.5\end{array}$ & $\begin{array}{c}32.1 \pm \\
5.6\end{array}$ & - & - \\
\hline \multicolumn{10}{|l|}{ Cap de Creus } \\
\hline $\begin{array}{c}\text { Canyon - } \\
\text { France(Cossa et } \\
\text { al., 2014) }\end{array}$ & Average & $\begin{array}{c}0.12 \pm \\
0.01\end{array}$ & $\begin{array}{c}0.13 \pm \\
0.01\end{array}$ & $\begin{array}{c}46.3 \pm \\
4.7\end{array}$ & $\begin{array}{c}85.4 \pm \\
3.4\end{array}$ & $\begin{array}{c}16.2 \pm \\
0.5\end{array}$ & $\begin{array}{c}29.3 \pm \\
2.3\end{array}$ & - & - \\
\hline $\begin{array}{c}\text { Selaata - } \\
\text { Lebanon(Abi- } \\
\text { ghanem, 2008) }\end{array}$ & Average & $0.5 \pm 0.3$ & $\begin{array}{c}0.3 \pm \\
0.1\end{array}$ & $\begin{array}{c}12.0 \pm \\
4.4\end{array}$ & $\begin{array}{c}145.2 \pm \\
30.7\end{array}$ & - & $\begin{array}{c}18.9 \pm \\
3.1\end{array}$ & - & $\begin{array}{c}0.04 \pm \\
0.01\end{array}$ \\
\hline $\begin{array}{c}\text { Akkar } \\
\text { background - } \\
\text { Lebanon }^{\text {b }}\end{array}$ & Average & $\begin{array}{c}0.08 \pm \\
0.01\end{array}$ & $\begin{array}{l}0.2 \pm \\
0.02\end{array}$ & $\begin{array}{c}10.9 \pm \\
2.44\end{array}$ & $\begin{array}{c}102.5 \pm \\
12.0\end{array}$ & - & $\begin{array}{c}11.1 \pm \\
2.8\end{array}$ & - & $\begin{array}{c}0.02 \pm \\
0.01\end{array}$ \\
\hline $\mathrm{UCC}^{\mathrm{c}}$ & & 0.05 & 2 & $17-20$ & 35.0 & $10-17$ & 14.3 & 1.5 & 0.06 \\
\hline
\end{tabular}

\subsection{Pore waters analysis}

Diagenetic tracers (ammonium, phosphate) were analyzed by using a Visible spectrophotometer (DR 2800, Hach Lange). Ammonium analysis were carried out using Merck Spectroquant (1.14752). Orthophosphate were analyzed by the method as described by Murphy and Riley (1958). Dissolved 
organic and inorganic carbon (DOC and DIC) were analyzed using a TOC-VCSH meter (Shimadzu) coupled with ASI-5000A module. DOC/DIC analysis were validated using a certified reference material (SUPER 05, Environment and Climate Change Canada). Dissolved minor/trace elements concentrations in pore waters were determined directly with HR - ICP/MS (Element 2 - Thermo Finnigan) by diluting by 10 .

\section{Results}

\subsection{Minor/Major/trace elements in sediment cores.}

Correlation between TM concentration of the three sediment cores are presented in Figure 2. $\mathrm{Al}$ and $\mathrm{Fe}$ were well correlated in D0, D1 $\left(r^{2}=0.71\right.$ and 0.93 respectively $)$ and they were not significantly correlated at $\mathrm{D} 2\left(\mathrm{r}^{2}=0.46\right)$. In addition, a significant correlation was observed between $\mathrm{Al}$ and $\mathrm{Rb}$ in $\mathrm{D} 0, \mathrm{D} 1$ and D2 $\left(r^{2}=0.76,0.90\right.$ and 0.86 respectively). Al and Mn were only strongly correlated in D0 and D1 $\left(r^{2}=0.90\right.$ and 0.76 respectively). Between D0, D1 and D2, Fe/Al ratios presented close average values $(1.27 \pm 0.15$, $1.47 \pm 0.06,1.57 \pm 0.26$ ). Results of grain size showed that predominant fraction size in all the studied sediments was between $20-60 \mu \mathrm{m}$ and $60-200 \mu \mathrm{m}$ (Supplementary information 1). In addition, the three sediment cores showed a superficial sediment enrichment in quartz, dolomite and calcite (Table2). Only D0 core showed the presence of ankerite and absence of pyrite in deep sediments.

Table 2: Average values of grain size, mineralogy, $P O C, T S, A l, M n$, Fe and $R b$ in the studied sediments

\begin{tabular}{|c|c|c|c|c|c|c|c|c|}
\hline & & Mineralogy & $\begin{array}{l}\text { POC } \\
(\%)\end{array}$ & $\begin{array}{l}\text { TS } \\
(\%)\end{array}$ & $\begin{array}{l}\text { Al } \\
(\%)\end{array}$ & $\begin{array}{l}\text { Mn } \\
(\%)\end{array}$ & $\begin{array}{l}\mathrm{Fe} \\
(\%)\end{array}$ & $\begin{array}{c}\mathrm{Rb} \\
\underset{\left(\begin{array}{c}\mu \mathrm{g} . \mathrm{g}^{-} \\
1\end{array}\right)}{ }\end{array}$ \\
\hline \multicolumn{9}{|c|}{ Quartz/Calcite/Ankerite/ } \\
\hline Do(8) & Average & Dolomite & $0.3 \pm 0.1$ & $0,5 \pm 0,2$ & $3.2 \pm 0.5$ & 0.03 & $4.0 \pm 0.2$ & $\begin{array}{r}13.7 \\
\pm 5.3\end{array}$ \\
\hline D1(15) & Average & Quartz/Calcite/Pyrite /Dolomite & $0.2 \pm 0.07$ & $0,6 \pm 0,2$ & $3.4 \pm 0.6$ & $0.04 \pm 0.01$ & $5.0 \pm 0.7$ & $\begin{array}{r}15.1 \\
\pm 3.2\end{array}$ \\
\hline D2(15) & Average & Quartz/Calcite/Pyrite/ Dolomite & $0.47 \pm 0.9$ & $0,8 \pm 0,2$ & $3.4 \pm 1$ & 0,04 & $5.1 \pm 0.5$ & $\begin{array}{c}11.2 \\
\pm 4 . .0\end{array}$ \\
\hline
\end{tabular}


The highest particulate organic carbon (POC) content $(3.3 \%)$ were found in superficial layer of the sediment core D2 then decrease rapidly along profile and reach low values ( $0.2 \%)$ (Figure 3). POC in the sediment cores D0 and D1 were lower than $0.5 \%$. In the sediment core D0, there was no correlation between POC and the studied elements except a significant negative correlation with POC and Fe and Co $\left(r^{2}=-0.83\right.$ and -0.67 , respectively). At the contrary, in the sediment core D1, there was a significant correlation between POC and all elements, for example with $\mathrm{As}\left(\mathrm{r}^{2}=0.75\right)$ and $\mathrm{Cd}\left(\mathrm{r}^{2}=0.45\right)$. In the sediment core $\mathrm{D} 2$, there was no correlation between $\mathrm{POC}$ and $\mathrm{Fe}, \mathrm{Pb}, \mathrm{Cd}$ and $\mathrm{Co}$, on the other hand, a significant correlation is observed between POC and $\mathrm{Cu}\left(\mathrm{r}^{2}=0.61\right)$. All the studied trace elements in the three sediment cores (Figure 2) present different correlation with POC due to different cores processes. Total content profiles of minor and trace elements are presented in Figure 3. The studied elements in the

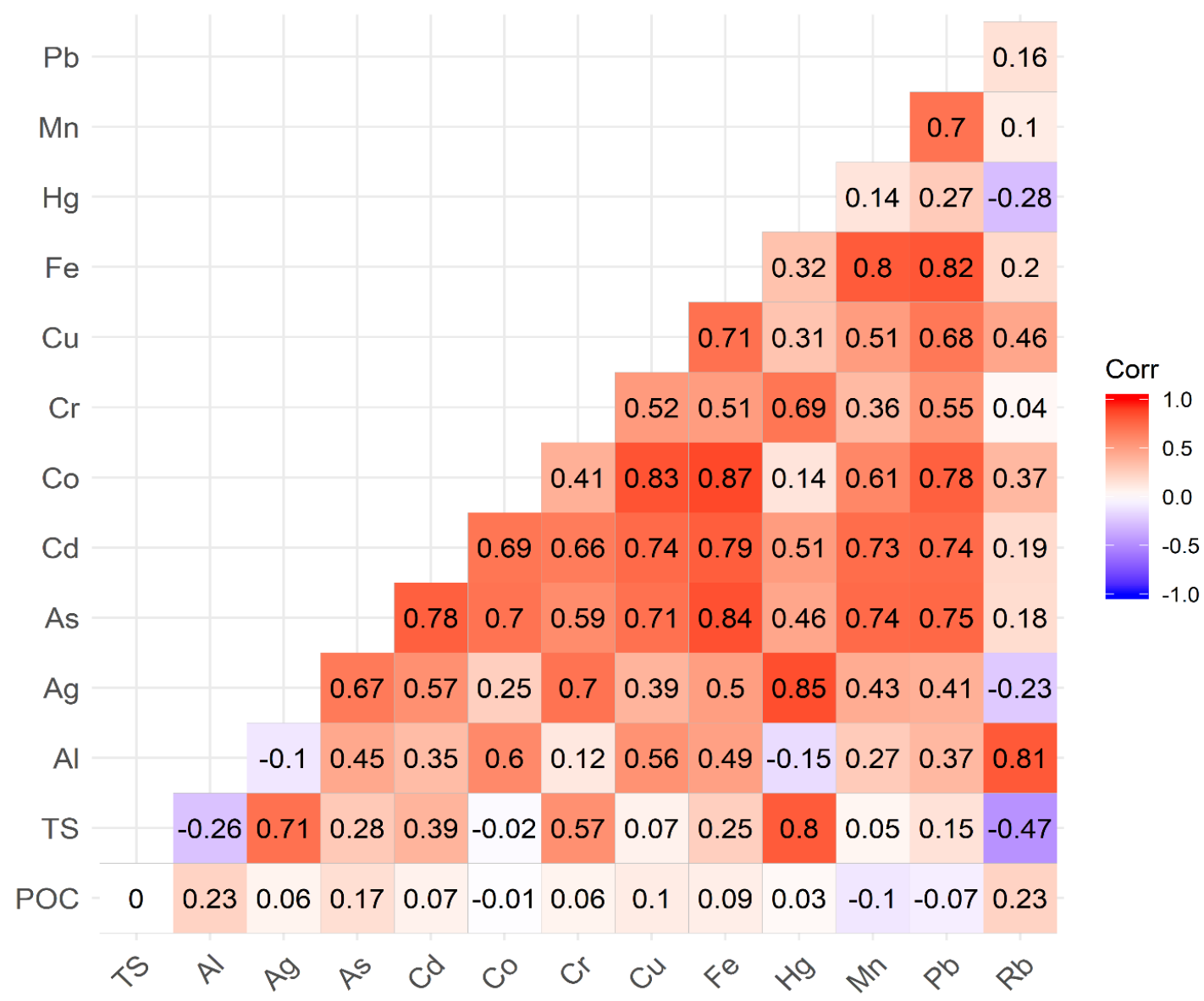

Figure 2: Correlation of POC, TS and all studied elements in the sediments.

sediment core D2, except Ag, show the same pattern: high superficial concentration and rapid decrease. A strong correlation between trace metals within the three sediment cores (Figure 2). Beside the strong 
correlation, solid profiles for $\mathrm{Mn}, \mathrm{Fe}, \mathrm{Co}, \mathrm{Cd}$ and $\mathrm{As}$ showed the same pattern variation along the three sediment profiles (Figure 3), where D0 showed the lowest concentration comparing to D1 and D2.

The Mn profile in cores fluctuated between 270 and $520 \mu \mathrm{g} . \mathrm{g}^{-1}$, and showed large amplitude peaks at sub-superficial layer. A high enrichment of trace elements in superficial sediment (from $-1 \mathrm{~cm}$ to $-3 \mathrm{~cm}$ ) was observed at cores $\mathrm{D} 1$ and $\mathrm{D} 2$ for $\mathrm{Pb}$ and $\mathrm{Ag}$, but for $\mathrm{Hg}$ and $\mathrm{Cu}$ the enrichment was observed only at D2. A constant and slight decrease of these trace metals levels was observed in deeper sediments of D2 (Figure 3). A superficial enrichment of trace elements (from $-1 \mathrm{~cm}$ to $-3 \mathrm{~cm}$ ) were observed at D2 and it was strongly and significantly correlated with POC and TS $\left(r^{2}=0.99\right)$. However, Ag profiles at point D1 showed a slight increase with depth and a peak at $-12 \mathrm{~cm}$, yet, D2 showed two peaks at superficial layer and at $-17 \mathrm{~cm}$ sediment depth. In contrast, D0 trace elements profiles showed a different trend, it showed more and less a constant profile with depth. At D0, a sub-superficial peak was detected for As and Cd associated to $\mathrm{Mn}$, in contrary, a peak was detected for $\mathrm{Ag}, \mathrm{Co}, \mathrm{Cu}$ and $\mathrm{Hg}$ associated to $\mathrm{Fe}$ (Figure 3). Spearman correlation was used to evaluate the source of elements and their influence on sediment characteristics. Positive correlation was observed between all studied trace elements, indicating a similar spatial distribution at the bay and same source input(Wang et al., 2017) (Figure 2). When studying each core alone, a significant positive correlation was still observed between most of trace elements in D1 but no more specifically in D0 or D2 where it appears poor correlations and sometimes negatives correlations (Supplementary information 2, Supplementary information 3). 

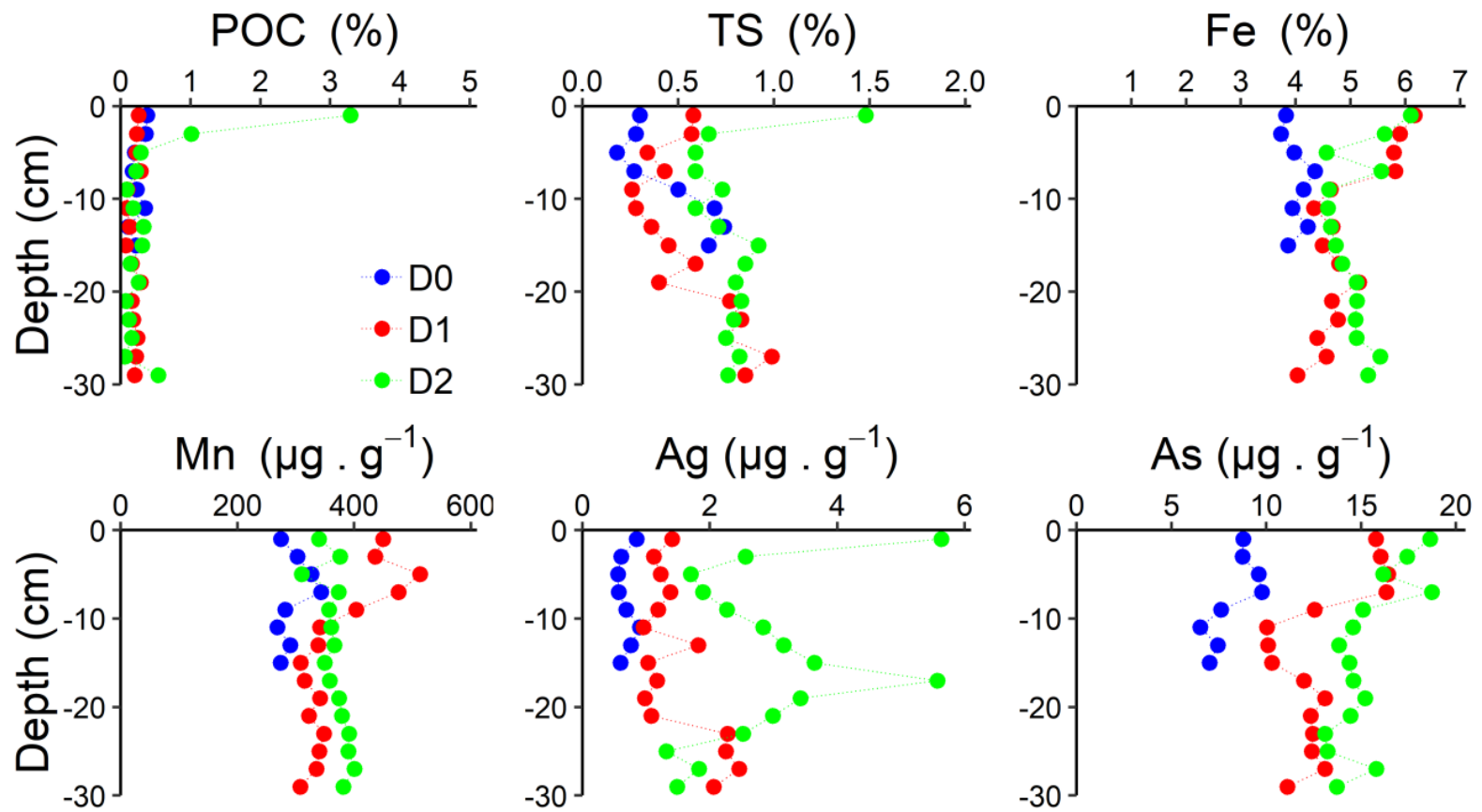

Co $\left(\mu g \cdot g^{-1}\right)$
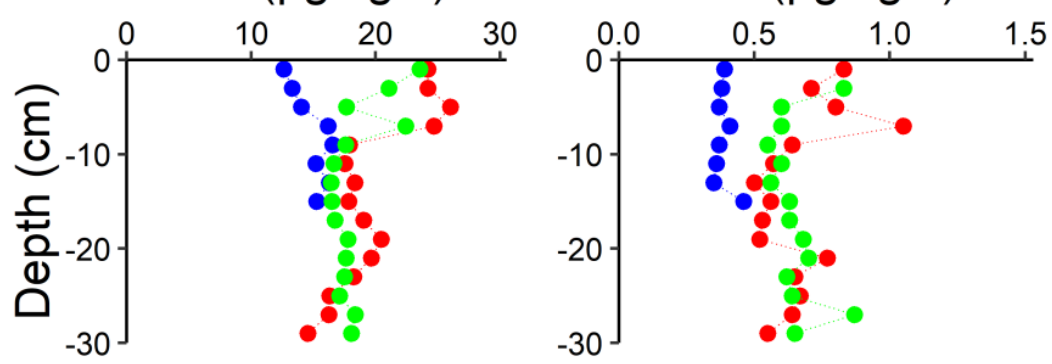

$\mathrm{Cd}\left(\mu \mathrm{g} \cdot \mathrm{g}^{-1}\right)$

$\mathrm{Cu}\left(\mu \mathrm{g} \cdot \mathrm{g}^{-1}\right)$

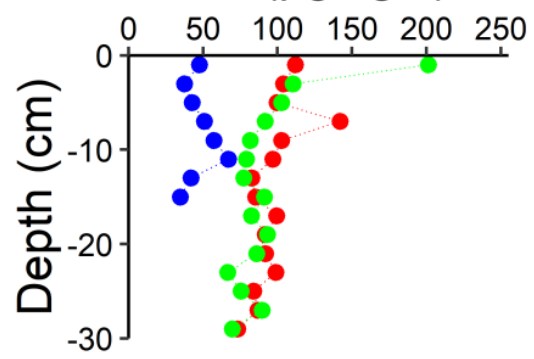

$\mathrm{Hg}\left(\mu \mathrm{g} \cdot \mathrm{g}^{-1}\right)$
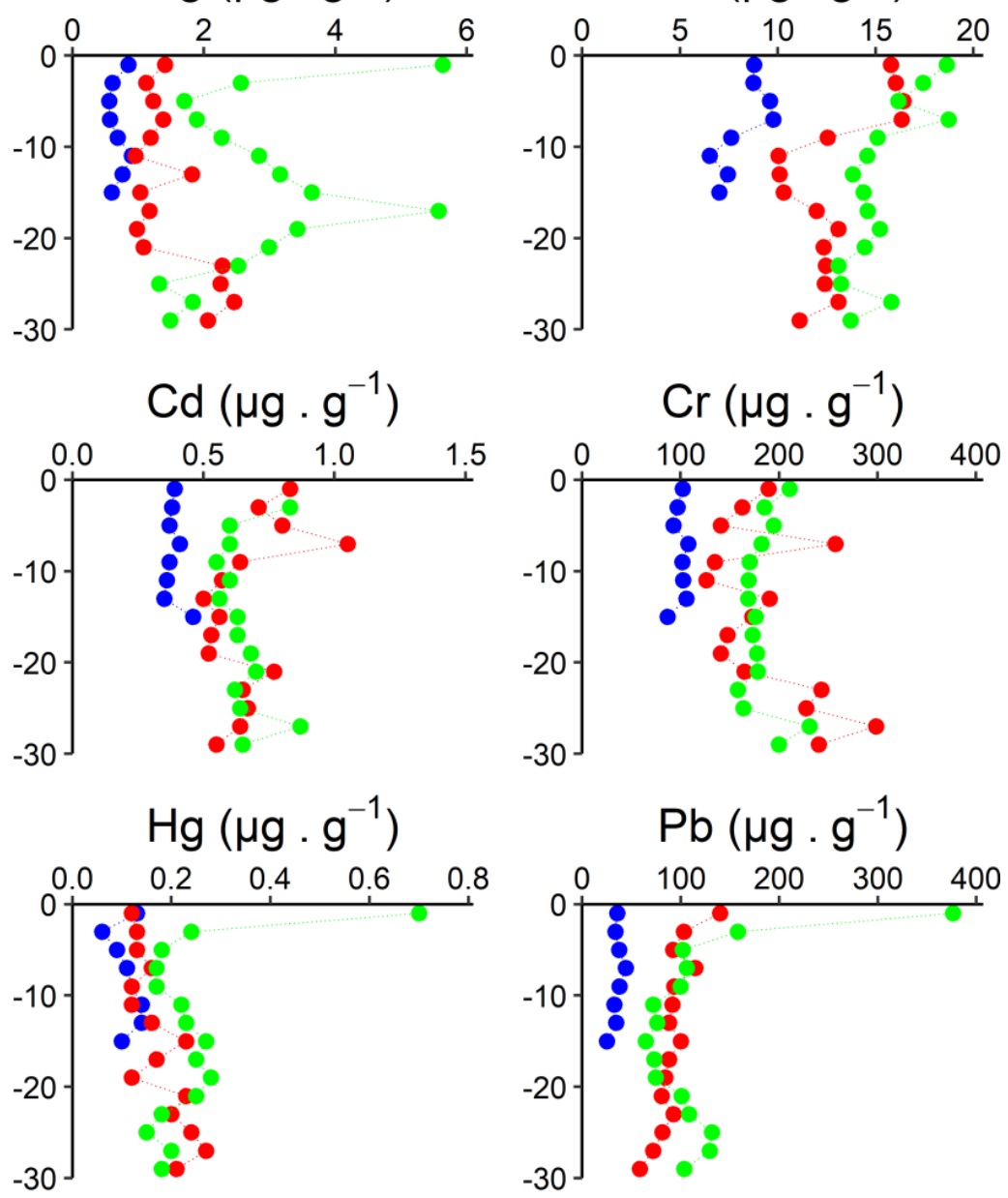

Figure 3: $\mathrm{POC}, \mathrm{TS}, \mathrm{Fe}, \mathrm{Mn}, \mathrm{Ag}, \mathrm{Cd}, \mathrm{Pb}, \mathrm{Co}, \mathrm{Cr}, \mathrm{Cu}, \mathrm{As}$ and $\mathrm{Hg}$ profiles in the three sediments cores DO (blue), D1 (red) and D2 (green).

As an example, $\mathrm{Cu}$ was correlated with $\mathrm{Mn}, \mathrm{Fe}, \mathrm{As}, \mathrm{Cd}$, $\mathrm{Co}$ and $\mathrm{Pb}$ in $\mathrm{D} 1\left(0.66<\mathrm{r}^{2}<0.78\right)$ which was not the case in $\mathrm{D} 0$ and $\mathrm{D} 2$ expect for $\mathrm{Cu} / \mathrm{As}$ correlation in $\mathrm{D} 2$ that were stronger $\left(\mathrm{r}^{2}=0.87\right) . \mathrm{Pb}$ was correlated with $\mathrm{Mn}$ and $\mathrm{Fe}$ in the three cores. Gathering all data: particulate organic/inorganic content (POC/PIC) and 33 elements (studied elements of this study and Li, Be, Rb, Mo, Sn, Sb, Cs, Tl, Bi, U, Al, Ti, V, Ni, 
$\mathrm{Sr}$ and $\mathrm{Ba}$ ) measured by ICP-MS, a principal component analysis (PCA) was performed using $\mathrm{R}$ toolboxes. In purpose, to see correlation and similarities between the three stations (D0, D1 and D2) and the studied elements. Three principal components (PC1, PC2 and PC3) were able to explain 52.1\%, 17.5 $\%$ and $11 \%$ respectively of the dataset variance (Figure 4 ).
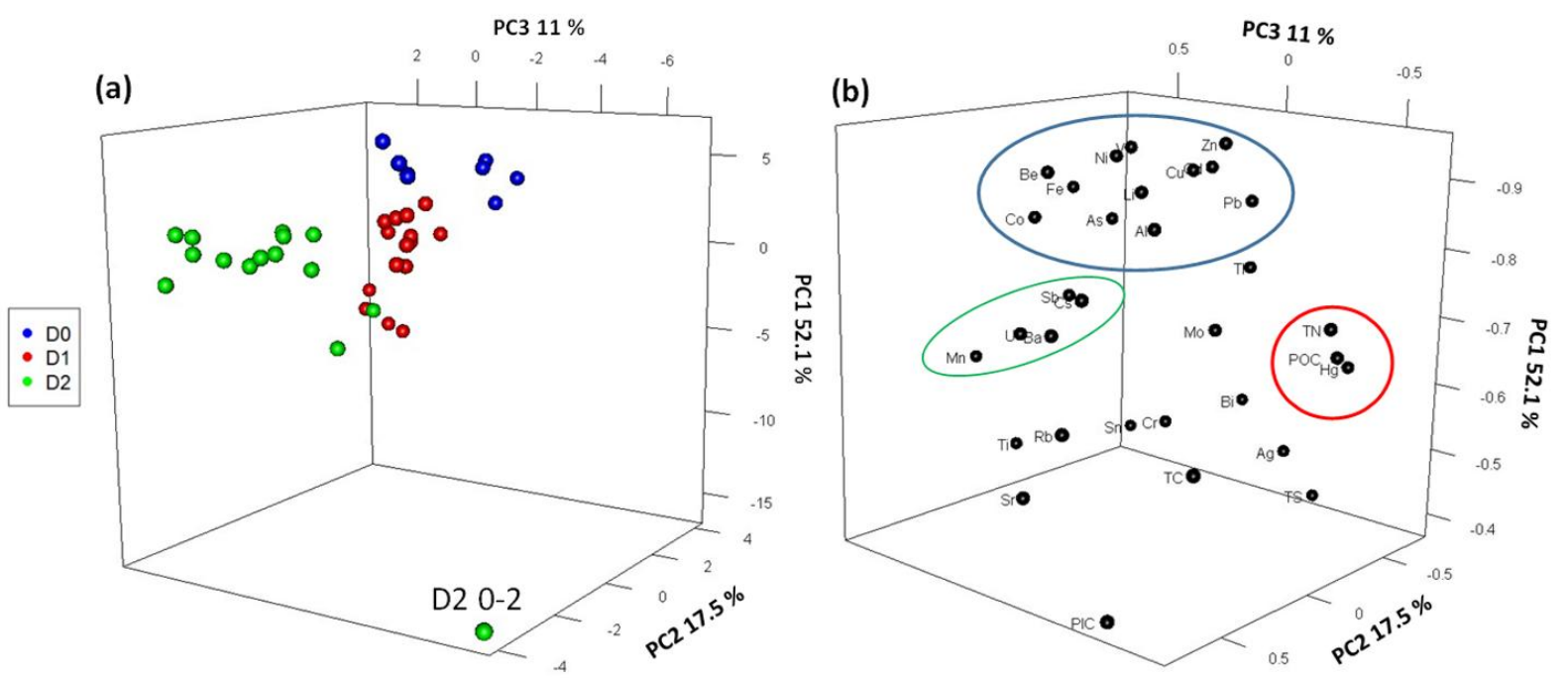

Figure 4: 3D representation of the three principal components obtained by PCA treatment of the dataset for (a) the sediments samples of DO (blue), D1 (red) and D2 (green) and (b) the 33 elements. Blue circle are elements driving $D 1$ (blue circle), red circle the correlation between $\mathrm{Hg}$ and POC and green circle elements driving D2.

The PCA results of the studied elements (Figure $4-\mathrm{b}$ ) showed that $\mathrm{Hg}$ is correlated with POC. Contaminants such as $\mathrm{Pb}, \mathrm{Cu}, \mathrm{Cd}$ and As were correlated with terrigenous elements such as $\mathrm{Al}, \mathrm{Li}$ and $\mathrm{Fe}$ evidencing a terrigenous source. On the other hand, the PCA projection of samples showed the sediments were distributed along with terrigenous elements (Figure 4- a). Moreover, the cores pool from D0 to D2 shift from terrigenous influence to more marine one ( $\mathrm{Mn}, \mathrm{U}, \mathrm{Ba}, \mathrm{Sb}, \mathrm{Sr}, \mathrm{Rb})$ reveling a core gradient. A particular behavior was observed at the first layer of D2 (Figure 4) which is driven by PIC; spearman's correlation also showed a strong correlation between PIC and all the studied elements in this specific layer. 


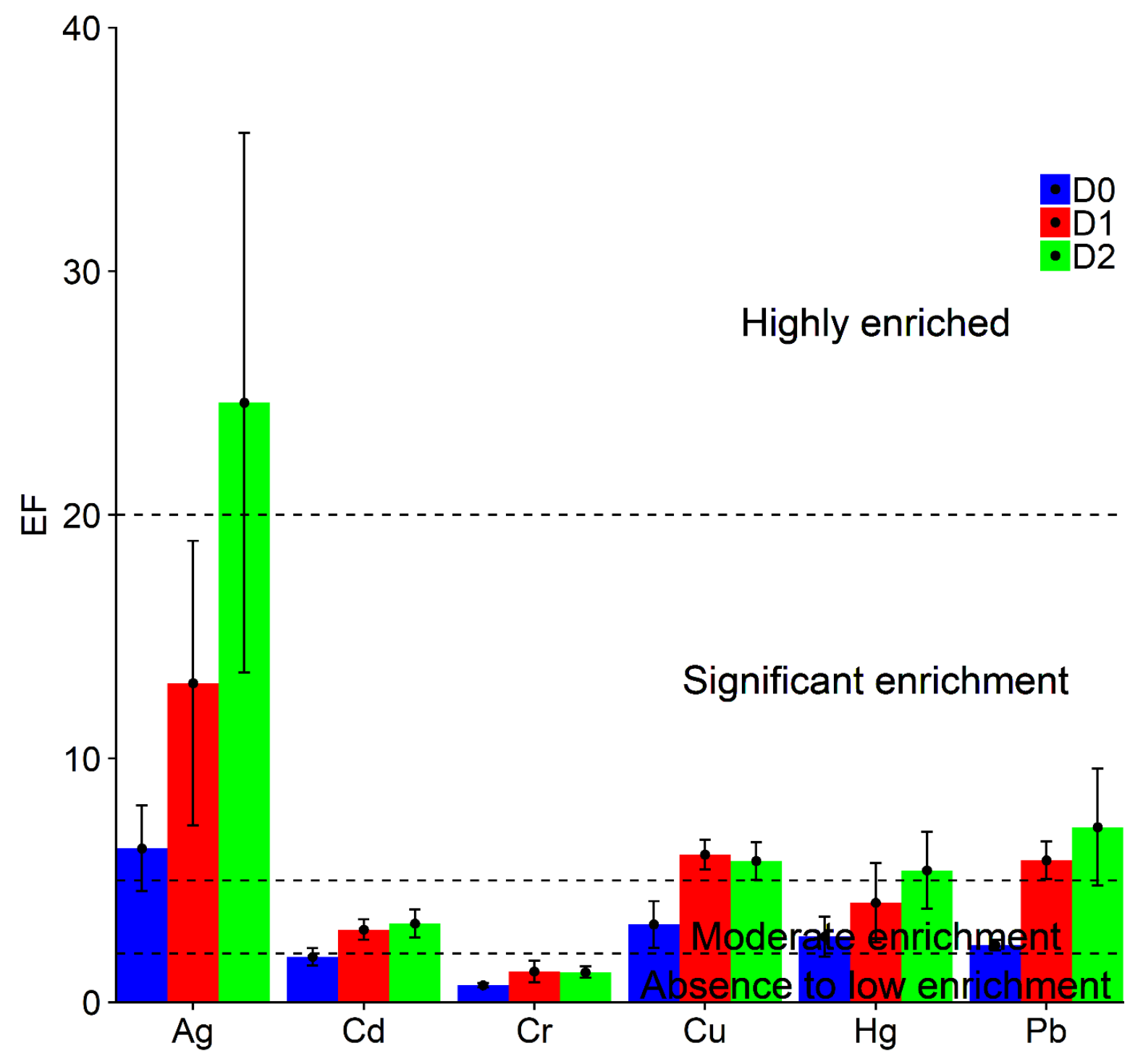

Figure 5: Average and standard deviation of metal enrichment factor (EF) in three sediments core "DO (blue), "D1" (red) and "D2" (green). The dashed lines indicate four of five categories cited in section 3.3.

Geochemical normalization was based on the concentration of a conservative element, in this work; aluminum was used for normalization since it had been the most commonly used in the geochemical literature.(Kontas, 2008; Mahu et al., 2015; Prajith et al., 2016; Tessier et al., 2011) In addition, aluminum is non-reactive to diagenetic changes in the sediments and it is a lithophilic element representing aluminosilicates. The natural background metal/Al ratio used in the normalized EF calculation was from a non-polluted area called Akkar located north of Beirut collected and analyzed for TM by Abi-ghanem, 2008.(Abi-ghanem, 2008) Enrichment factors calculated for Ag, Cd, $\mathrm{Cr}, \mathrm{Cu}, \mathrm{Hg}$ and $\mathrm{Pb}$ were presented in (Figure 5). Enrichment factor of trace elements showed significant enrichment to 
moderate enrichment for $\mathrm{Ag}, \mathrm{Pb}, \mathrm{Cu}, \mathrm{Hg}$ and $\mathrm{Cd}$ (Figure 5). These studied sediments were enriched in metals in the following order: $\mathrm{Ag}>\mathrm{Pb}>\mathrm{Cu}>\mathrm{Hg}>\mathrm{Cd}>\mathrm{Cr}$. To be noted that $\mathrm{D} 2$ and $\mathrm{D} 1$ were found more enriched than D0. EF values were detected above 20 (Highly Enriched) just for Ag at core D2. In addition, for all the elements cited, $\mathrm{EF}$ values indicated even a significant enrichment for $\mathrm{Pb}, \mathrm{Cu}$ at $\mathrm{D} 1$ and D2 and for $\mathrm{Hg}$ at D2. Alternatively, a moderate enrichment for $\mathrm{Cu}, \mathrm{Pb}$ at D0 and for $\mathrm{Hg}$ at $\mathrm{D} 1$ and D0. On the other hand, no or minimal pollution was detected for Cr.

\subsection{Selective extractions}

Total concentration of trace elements was not sufficient to estimate mobility of trace elements and their bioavailability in sediments by measuring. So selective extractions were applied on sediments with three extractants $(\mathrm{HCl} 1 \mathrm{M}$, ascorbate $\mathrm{pH}=8.2, \mathrm{NaOH} 0.1 \mathrm{M})$ in order to clarify the distribution of trace elements in the solid phase of the sediment (Audry et al., 2006). Averaged percentages of elemental extractability all along the sediment cores in the three points D0, D1 and D2 are presented in Figure 6, representing the potential mobile fraction of an element (Leleyter and Baraud, 2005). Extraction with ascorbate give a primary information about easily reactive reducible Fe and Mn (oxy)hydroxides (Canavan et al., 2006) which are terminal electron acceptors in the organic matter degradation reaction and also bearing phases for trace elements in suboxic zone. Trace metals percentages extracted with ascorbate were very low and tended to be negligible expect for As. In this study, the order of extractable elements by ascorbate solution was $\mathrm{Cd} \approx \mathrm{Cu} \approx \mathrm{Ag} \approx \mathrm{Pb}<\mathrm{Mn} \approx \mathrm{Cd}<\mathrm{Cr}<\mathrm{Fe} \approx \mathrm{Co}<$ As. Along D0, the averaged percentage showed that As was the most extracted $(12.9 \pm 3.5 \%)$ then $\mathrm{Co}(5.7 \pm 0.8 \%)$ and $\mathrm{Cr}(1.9 \pm 0.3 \%)$ were slightly extracted with ascorbate solution. However, $\mathrm{Pb}, \mathrm{Cd}, \mathrm{Cu}$ and $\mathrm{Ag}$ were not extracted with ascorbate. Alkaline extraction was negligible for most of elements expect for $\mathrm{As}, \mathrm{Cu}$ and $\mathrm{Cd}$. Arsenic was the most extracted element $(31.4 \pm 3.0 \%)$, then $\mathrm{Cu}(7.4 \pm 2.0 \%)$ and $\mathrm{Cd}(3.0 \pm 1.4 \%)$ were slightly extracted with alkaline extraction. Acid extraction allowed the extraction of potentially "bioavailable" trace elements by dissolving oxides and carbonates (Dang et al., 2015; Larrose et al., 2010). The extracted percentage with $\mathrm{HCl}$ varied between $4 \%$ and $87 \%$ depending on element. As an example, in D2, arsenic was the less extracted element $(4.4 \pm 2.1 \%)$ by $\mathrm{HCl}$ compared to $\mathrm{Cd}(56.2 \pm 6.5 \%)$ and $\mathrm{Pb}(53.1 \pm 5.1$ \%). $\mathrm{Ag}, \mathrm{Pb}, \mathrm{Cd}$ and $\mathrm{Cu}$ were the most extracted elements with $\mathrm{HCl}$ extraction. For all the sample, the order of extractable elements by $\mathrm{HCl}$ was $\mathrm{As}<\mathrm{Cr}<\mathrm{Co}<\mathrm{Cu}<\mathrm{Ag}<\mathrm{Pb} \sim \mathrm{Cd}$, similar to the order obtained in sediment rich in pyrite (Scholz and Neumann, 2007). 

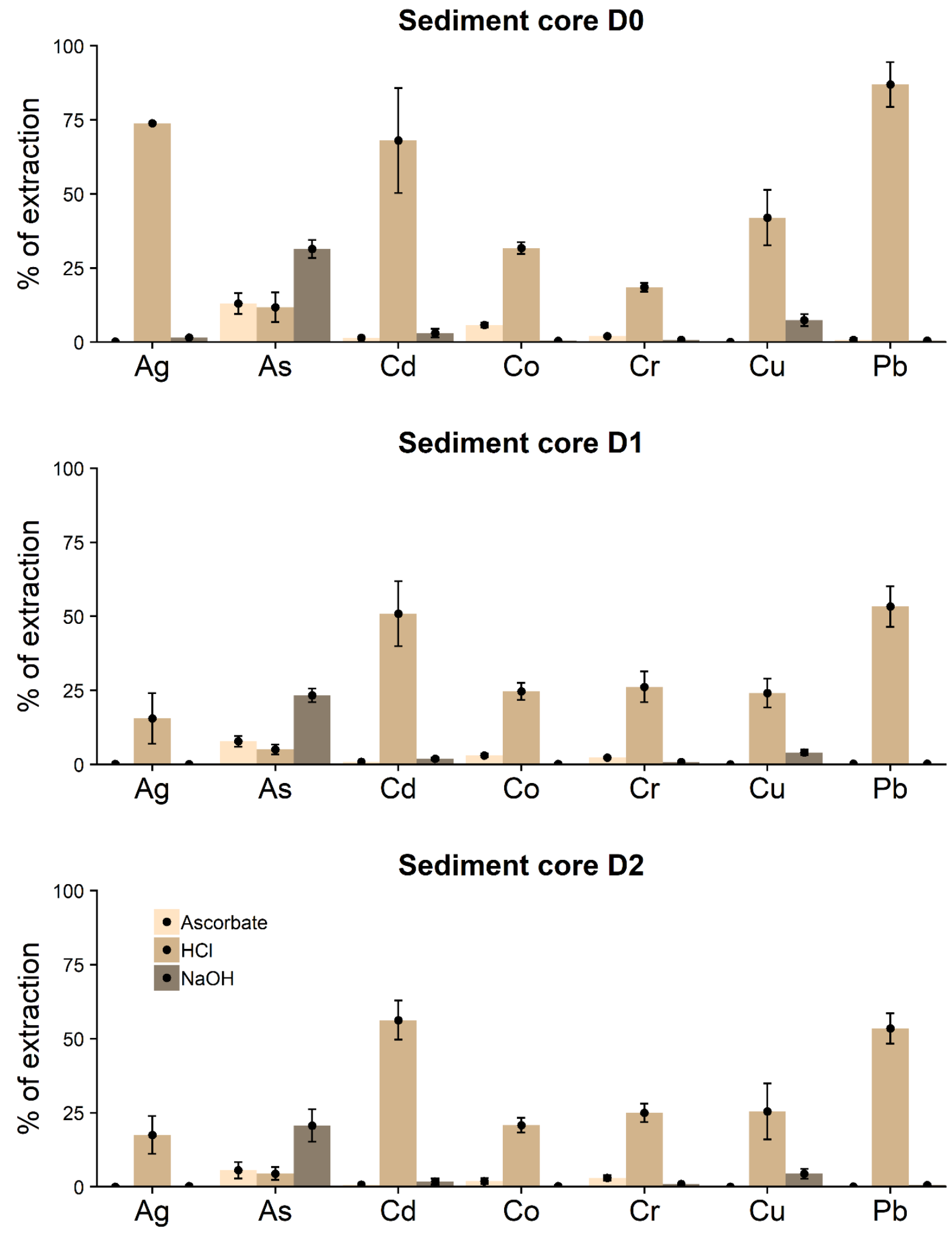

Figure 6: Mean percentage of trace elements extracted with Ascorbate $\mathrm{pH}=8.2, \mathrm{HCl} 1 \mathrm{M}$ and $\mathrm{NaOH} 0.1 \mathrm{M}$ for each sediment cores " $D O$ ", " $D 1$ " and " $D 2$ " along all sediments depth. 


\subsection{Column and Interstitial water profiles}

In water column, oxygen measurements showed $99-85.1 \%$ saturation at the first meters of water column depth and oxygen was partially consumed (39\% sat of $\mathrm{O}_{2}$ ) below $3 \mathrm{~m}$ of water depth. In cores D0, D1 and $\mathrm{D} 2, \mathrm{pH}$ was around $8.0 \pm 0.1$ in surrounding column waters and fluctuated from $7.2-8.0$ in interstitial waters. In sediment, redox potential values of interstitial water decreased slowly in D1 and D2 all along the core and reached $-200 \mathrm{mV}$, however, redox potential decreased sharply from the surface to reach more negative values $-300 \mathrm{mV}$ in $\mathrm{D} 0$ (Figure 7).

Dissolved organic carbon (DOC) tended to increase with depth at D1 and D2, while in D0, DOC fluctuated but increased with depth. $\mathrm{NH}_{4}{ }^{+}$profiles at D1 and D0 increased with depth, unlike D2 where a superficial peak is observed. To be noted that DOC was correlated with $\mathrm{NH}_{4}{ }^{+}$and $\mathrm{PO}_{4}{ }^{3-}\left(\mathrm{r}^{2}=0.63\right)$ only in D0. Mn (oxy)hydroxides reduction zones and release of dissolved Mn occurred at upper layer in D2 (at -3 $\mathrm{cm}$ ) and a little bit deeper in D0 and D1 (at $-7 \mathrm{~cm}$ ). At deeper sediment layers, Mn concentrations decreased sharply at D2 (at $-5 \mathrm{~cm})$ and D0 (at $-10 \mathrm{~cm}$ ) where it tended to be negligible. In contrast, Mn concentrations decreased slowly at D1 but not completely removed. Furthermore, in D0 and D2, pore water peaks of Fe appeared above the large solid phase Fe peaks, yet, in D1 was vice versa. D0 showed a superficial peak at SWI interface with a concentration level of $680 \mathrm{nM}$ (Figure 7). For D2, dissolved Fe profile showed a superficial peak and Fe concentrations were very low comparing to Fe contents in D0 and D1 and fluctuating between 1,000 and 3,000 nM (Figure 7). The highest concentration of dissolved Fe $(20 \mathrm{mM})$ was observed at D1 at $-11 \mathrm{~cm}$ of sediment depth (Figure 7).

Concentrations of trace elements and DOC in column water did not vary significantly. In addition, a slightly increase in the concentration of some studied elements $(\mathrm{Pb}, \mathrm{Cu}, \mathrm{Co}$ and $\mathrm{As}$ ) was detected in the supernatant water. The $\mathrm{D} 1$ interstitial water sediments core showed superficial peaks of dissolved $\mathrm{Pb}$ in the oxic/suboxic boundary. A strong correlation was observed between $\mathrm{Fe}$ and $\mathrm{Pb}$ in $\mathrm{D} 1\left(\mathrm{r}^{2}=0.72\right)$ and $\mathrm{D} 2$ $\left(r^{2}=0.86\right)$. For dissolved Co, a sub-superficial layer peak was detected at D0 associated with $\mathrm{Mn}\left(\mathrm{r}^{2}=\right.$ $0.81)$ and $\mathrm{Fe}$ (oxy)hydroxide $\left(\mathrm{r}^{2}=0.61\right)$ in the reduction zone. On the other hand, dissolved Co profiles at D1 and D2 showed two peaks. The first one at superficial or sub-superficial layers at D1 associated with Mn $\left(r^{2}=0.88\right)$ and Fe (oxy)hydroxide reduction zone $\left(r^{2}=0.71\right)$ and slightly one with Mn oxides in D2 $\left(r^{2}=0.41\right)$; the second peak was observed in deeper layer associated with DOC where a strong correlation was observed between Co and DOC in D1 and D2 $\left(\mathrm{r}^{2}=0.80\right)$. At D0 and D2, dissolved Cr profiles tended to increase with sediment depth. 


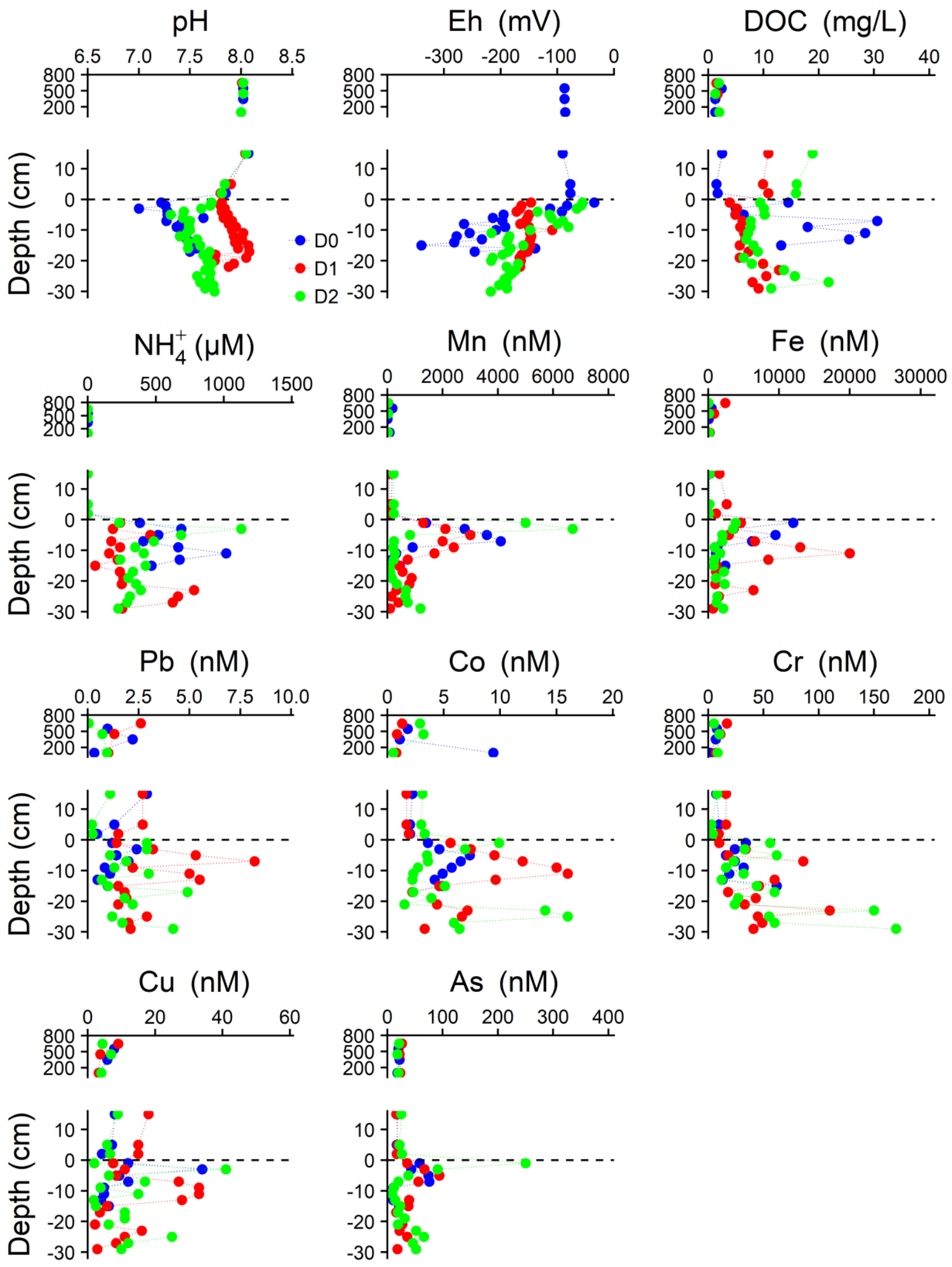

Figure 7: $p H$, Eh, dissolved organic carbon, nutrients and dissolved trace elements profiles in pore waters extracted at the three sediments cores "D0" (blue), " $D 1$ " (red) and "D2" (green). 
However, at D1, dissolved profile Cr showed two peaks, one at sub-superficial layer and the second at deeper layer attached to DOC; dissolved $\mathrm{Cr}$ in these layers were correlated with DOC $\left(r^{2}=0.50\right)$. For dissolved $\mathrm{Cu}$, profiles showed a superficial peak in the three sediment cores D0 $(-3 \mathrm{~cm})$, D1 $(-11 \mathrm{~cm})$ and D2 $(-3 \mathrm{~cm})$. In D0 and D2 $\mathrm{Cu}$ was associated at the oxic/suboxic boundary in the Mn/Fe reduction zone and only with Fe reduction zone in D1. The release of dissolved arsenic occurred immediately below the SWI at D0, D1 and D2 indicating a release during organic matter oxidation and Mn or Fe oxides reduction.

\section{Discussion}

\subsection{Sediments composition and solid profiles}

Grain size affects the accumulation of metals in sediments and fine fraction promotes the accumulation of trace elements in the sediments.(Blott S.J. and Pye K., 2001; Cauwet, 1987; Ujević et al., 2000) Mean percentage of grain size showed that the majority of particles were very coarse silt $(20-50 \mu \mathrm{m})$ or very fine sand $(50-200 \mu \mathrm{m})($ Supplementary information 1) at the three sediment cores D0, D1 and D2. These results were co-variant with the mineralogy of the studied zone, rich in quartz, calcite and dolomite (Table 2). Elements concentrations such as $\mathrm{Al}, \mathrm{Rb}, \mathrm{Fe}$, and $\mathrm{Mn}$ (Table 2) at the three points indicated that the mineral composition seems constant during sedimentation processes. The significant correlation between elements such as $\mathrm{Al} / \mathrm{Fe}$ or $\mathrm{Al} / \mathrm{Rb}$ or $\mathrm{Al} / \mathrm{Mn}$ in $\mathrm{D} 0$ and $\mathrm{D} 1$ reflected a common source for these elements and indicated a signature of terrigenous fine particle such as aluminosilicates and oxyhydroxides, however, the source in D2 do not present a completely to terrigenous source. These results could be related to high mixing of sediments or to the influence of alluvial continental deposits by Beirut river (Abi-Ghanem et al., 2009), such deposits came with the run-off of Beirut River after a big episodes of precipitation. This behavior was observed also with ascorbate and $\mathrm{HCl}$ extraction results. The ascorbate extraction showed an accumulation of $\mathrm{Fe}$ and $\mathrm{Mn}$ that correspond to Fe/Mn (oxy)hydroxide (Haese et al., 2000; Rigaud et al., 2013). In plus, ascorbate extraction of Al, Mn and Fe were low comparing to acid extraction but they showed the same trend and they were strongly correlated in the sediment cores D0 $\left(\mathrm{r}^{2}=\right.$ $0.83)$ and $\mathrm{D} 1\left(\mathrm{r}^{2}=0.99\right)$, less in $\mathrm{D} 2\left(\mathrm{r}^{2}=0.45\right)$. The difference could be due to the presence of oxides, carbonates and monosulfide minerals in the sediments (Dang et al., 2014; Haese et al., 2000). The highest POC content detected at the superficial layer of D2 (Figure 3) indicated a superficial enrichment, supported by the highest dissolved organic carbon in the supernatant waters at D2, then a slight decrease with depth (Figure 7). This could be related to terrestrial OM inputs from rivers, to urban sewage 
discharge or to biological production (Álvarez-Iglesias et al., 2006). POC profiles in D0 and D1, present lower starting point in D2, but also decreased with depth.

Vertical variability of trace elements presented in Figure 3, showed disrupted profiles of all studied elements with depth implied must probably the mixing sediment process "resuspension", especially that this bay was very well known as a docking area. The Spearman's correlation showed a significant positive correlation between concentrations of $\mathrm{Al}, \mathrm{Fe}$ and the anthropogenic trace elements $(\mathrm{Cd}, \mathrm{Pb}, \mathrm{Co}$, $\mathrm{Cr}, \mathrm{Cu}$ and $\mathrm{As}$ ) in this bay (Figure 2) and not Ag which was slightly correlated with POC (see section 4.1). These indicated that the primary accumulation of trace elements in the bay was governed by deposition of terrigenous material, particularly particles associated with terrigenous organic matter and $\mathrm{Fe}$ and $\mathrm{Mn}$ oxides and (oxy)hydroxides. Trace elements chemical extraction results appeared to be similar in the three sediments cores. These trace elements $(\mathrm{Ag}, \mathrm{Cd}, \mathrm{Pb}, \mathrm{Co}, \mathrm{Cr}$ and $\mathrm{Cu}$ ) were more extracted with acid extraction, indicating they are mostly associated to exchangeable-carbonates or oxides. The high acid extraction percentage observed for $\mathrm{Cu}$ highlight the presence of a $\mathrm{Cu}$ desorption from organic sites or $\mathrm{Cu}$ release from oxides (Adamo et al., 2005). However, As was the most extracted with ascorbate and alkaline extraction. In plus, $\mathrm{Cu}$ was slightly extracted by alkaline extraction. This alkaline extraction of As and $\mathrm{Cu}$ could be attributed to the stable and soluble complexes formed with dissolved organic matter (Dang et al., 2015; Ho et al., 2012). As, Co, Cr and Cd were slightly extracted with ascorbate suggesting an interaction between these elements and $\mathrm{Mn} / \mathrm{Fe}$ (oxy)hydroxide fraction but the contribution of other phases such as FeS are not negligible (Haese et al., 2000; Rigaud et al., 2013). These results confirmed the association of the studied trace elements to terrigenous organic matter and $\mathrm{Fe}$ and $\mathrm{Mn}$ oxides and (oxy)hydroxides which could be imported by the Beirut river or the industrial effluents or Beirut Harbor activities. Comparing concentrations of these trace elements in the three sediment cores to background level in the upper continental crust given by Wedepohl, 1995 or to background level of Akkar region (Table 1), the sediments in the area showed a highly mean content for $\mathrm{Cd}, \mathrm{Pb}, \mathrm{Cu}$, As and $\mathrm{Hg}$. Comparing to other studies in the Mediterranean Sea or outside (Table1), these studied sediments were highly contaminated especially, with $\mathrm{Ag}, \mathrm{Cd}, \mathrm{Pb}, \mathrm{Cu}$ and $\mathrm{Hg}$. High concentrations of trace elements were observed, especially, in sediment core D2. The superficial enrichment of trace elements and the strong correlation between trace elements and superficial high content of POC and Fe detected at station D2 indicated that these elements could have terrestrial inputs from the river or point source input. This core was collected in front of fuels containers and an industrial effluent and under the influence of ships, which could be source of pollution. These results were confirmed with the EF values (Figure 5). Alkaline extraction showed a high percentage in superficial layer especially for $\mathrm{As}$ and $\mathrm{Cu}$ even for $\mathrm{Ag}$ and $\mathrm{Cd}$ (data not shown). These could be attributed to the stable and soluble complexes formed with dissolved 
organic matter, as for $\mathrm{Cd}$, could be attributed to the control of OM on the biogeochemistry of Cd.(Dang et al., 2015; Ho et al., 2012) In addition, acid extraction in these superficial layers showed the highest percentage of extraction indicating that the studied elements in the first layers are associated to oxides and carbonates (Dang et al., 2015; Larrose et al., 2010). These results indicated the influence of industrial activities in this bay and the presence of solid waste all around. This significant pollution could also be due to antifouling paints based on $\mathrm{Cu}$ or $\mathrm{Pb}$ or also to inputs arising from boat repainting (Burton et al., 2005). Noteworthy that the industrial effluents or urban storm water runoff transported without any treatment to the bay from the urbanized region by Beirut River could be a major source of trace metal pollution in the region. On the other hand, it could be due to resuspension of sediment as this area is faced to numerous activities such as rising of navy ships wrecks and this was reflected by a homogeneous distribution of metals (Briant et al., 2013). All these results confirmed the moderate and significant level of contamination in the St-Georges Bay sediments and highly contaminated with Ag. In addition, PCA results confirmed that the studied sediments of the three stations followed the contaminants elements which were correlated with terrigenous elements (clay-component elements $\mathrm{Al}$ and $\mathrm{Fe}$ ) showing a contamination all down the core expect for the first layer of D2. These sediments mostly had anthropogenic origins from terrestrial inputs, which can be Beirut River or industrial effluents in this region. Such results confirmed the contamination of St-Georges Bay with $\mathrm{Pb}, \mathrm{Cd}, \mathrm{Cu}, \mathrm{Cd}, \mathrm{As}$ and particularly Ag. The studied elements showed a clear correlation between the anthropogenic and terrigenous and this could be related to their mixed origins and a significant contamination comparing to the background level.

\subsection{Early diagenesis tracer evidences}

At the three sites, $\mathrm{pH}$ was around 8 which is the common range for marine sediments (Burton et al., 2005) and it is a well-known factor that influence heavy metals transfer behavior in sediments (Peng et al., 2009). At the three points, sediments were strongly reduced (Figure 7) and reflected completely anoxic sediments (Burton et al., 2005) starting from - $14 \mathrm{~cm}$ of sediment depth in D1 and D2. During early diagenesis, the distribution of major/minor and trace elements between pore waters and sediments is affected by a set of complex processes (Heggie and Lewis, 1984). Many processes can lead to the removal and/or the release of elements from pore waters such as redox zone or biogenic material (Shaw et al., 1990). It is also important to note that the behavior of elements differ during early diagenesis in the same sedimentary environment. The common diagenetic sequence was clearly noticeable in the three sediment cores. Dissolved organic carbon (DOC) tended to increase with depth at the three sediment cores, which could be related to the mobilization of particulate carbon to the water. Ammonium profiles showed peaks at different sediment depths, i.e., at $-10 \mathrm{~cm}$ for D0, and below $-20 \mathrm{~cm}$ depth for D1 which 
indicated sub-oxic degradation (Haese et al., 2000), unlike D2 where a peak was observed directly at superficial layer. The decrease of POC (Figure 3) in sediments and the increase of $\mathrm{PO}_{4}{ }^{3-}$ (Data not shown), $\mathrm{NH}_{4}{ }^{+}$and DOC with depth (Figure 7) in pore waters reflected directly the degradation of OM deriving primary and secondary redox reactions (Anschutz et al., 2007; Rigaud et al., 2013). A high mobilization of $\mathrm{Mn} / \mathrm{Fe}$ occurred below the sediment-water interface (SWI) due to the reduction of $\mathrm{Mn} / \mathrm{Fe}$ (oxy)hydroxides and released $\mathrm{Mn}^{2+}$ and $\mathrm{Fe}^{2+}$ into the pore waters (Figure 7). The release in the $\mathrm{Mn}$ reduction zone was attributed to the release of metals associated with Mn oxides in the solid phase (Shaw et al., 1990). Mn oxides reduction zones and release of dissolved Mn occurred at upper layer in the studied sediments. Fe (oxy)hydroxides reduction zones occurred after Mn oxide reduction but the order changed or overlap sometimes depending on inputs of reactive $\mathrm{OM}$ and bioavailability of $\mathrm{Fe}$ (oxy)hydroxides in the sediments (Canavan et al., 2006; Canfield et al., 1993). The high Mn peaks next to SWI are attributed to the reduction of amorphous Fe (oxy)hydroxide (Scholz and Neumann, 2007).

\subsection{Trace metals and early diagenesis}

Almost at the 3 sediment cores, the release of trace elements was immediately below the SWI and occurs in the $\mathrm{Fe}$ and $\mathrm{Mn}$ (oxy)hydroxide reduction zone. Concentrations of trace elements in pore waters were higher than in the overlying water (Figure 7) indicating a possible diffusive flux from sediment to the water column (Rigaud et al., 2013). Dissolved Co profiles in the sediments and pore waters showed that $\mathrm{Co}$ was released in pore waters during reduction of $\mathrm{Mn} / \mathrm{Fe}$ (oxy)hydroxide (Figure 7), indicating that $\mathrm{Co}$ was adsorbed onto manganese (oxy)hydroxide phases in the sediments as evidenced in different studies (Achterberg et al., 1997; Heggie and Lewis, 1984; Tankere-Muller et al., 2007). These results were confirmed with the strong correlation between Co and Mn or Fe; moreover, Co was mostly extracted with acid extraction. The second peak observed in station D1 $(-27 \mathrm{~cm})$ and D2 $(-25 \mathrm{~cm})$ was strongly correlated with DOC in deeper layer. Furthermore, Co was also slightly extracted with alkaline extraction, indicating that Co could be complexed to organic matter as described by different studies (Algeo and Maynard, 2004; Zhang et al., 1990) which showed the affinity of cobalt to humic substances and organic ligands. Dissolved Cr profiles tended to increase with sediment depth, expect for D1, where two peaks, at sub-superficial layer $(-11 \mathrm{~cm})$ and at deeper layer $(-27 \mathrm{~cm})$ are present and associated to DOC. The release of $\mathrm{Cr}$ in superficial layer was due to reduction $\mathrm{Mn} / \mathrm{Fe}$ (oxy)hydroxide. The increase of dissolved $\mathrm{Cr}$ concentrations in pore waters corresponded also to an increase in DOC concentrations, to an increase in Cr levels in sediment (Figure 3, Figure 7). And to a slight increase with depth in $\mathrm{Cr}_{\mathrm{Asc}}$ and $\mathrm{Cr}_{\mathrm{NaOH}}$ profiles (Supplementary information 4). By this behavior, we could predict a strong affinity of $\mathrm{Cr}$ with OM and the presence of humic complexes (Shaw et al., 1990). The release of metals at the SWI or/and in 
the reduction zone of Mn was attributed to biogenic materials or particles degradation which contain metals (Shaw et al., 1990). Release of $\mathrm{Cu}$ into pore waters occurred in the $\mathrm{Mn} / \mathrm{Fe}$ reduction zone, which indicated that $\mathrm{Cu}$ was released from organic matter or from reductive dissolution of $\mathrm{Fe}$ (oxy)hydroxide in oxic/suboxic surface layer of the sediment. In the sediment, $\mathrm{Cu}$ is normally associated with fresh and easily metabolizable organic matter or adsorb onto particulate $\mathrm{Mn} / \mathrm{Fe}$ (oxy)hydroxides (Algeo and Maynard, 2004; Scholz and Neumann, 2007). This hypothesis was also supported with the results of acid and alkaline extraction and the strong correlation between $\mathrm{Cu}$ and $\mathrm{Fe}\left(\mathrm{r}^{2}=0.76\right)$ in the sediment of the three sediment cores. The negligible values of $\mathrm{Cu}_{\mathrm{Asc}}$ in the four sediment cores indicated the $\mathrm{Cu}$ is not associate to reducible fraction (amorphous $\mathrm{Fe}$ oxides). The release of dissolved arsenic occurred immediately below the SWI in the three cores was related to the reductive dissolution of $\mathrm{Mn} / \mathrm{Fe}$ (oxy)hydroxide into pore waters in the form of As(III) and /or As(V), especially, that As was extracted with ascorbate and acid extraction. This behavior was similar to these observed in other studies (Chaillou et al., 2003; Couture et al., 2010; Dang et al., 2014). The second peak observed at deep layers of D1 (- 27 $\mathrm{cm})$ and D2 $(-25 \mathrm{~cm})$ (Figure 7) could be linked to the presence of fresh organic matter from different source as there is a strong correlation between DOC and As in deep layers; moreover, As was mostly extracted with alkaline solution. $\mathrm{Pb}$ was mobilized near the SWI or at intermediate layer in the three cores during the reactive $\mathrm{Fe}$ oxides reduction or the aerobic degradation of organic matter. In addition, $\mathrm{Pb}$ was only extracted with acid extraction (Figure 6) confirming the release from these carrier phases and participating in the cycle of Fe dissolution, diffusion and re-precipitation (Gobeil and Silverberg, 1989).

\section{Conclusion}

This study confirmed the significant contamination of the St-Georges Bay sediments, presenting significant $(\mathrm{Hg}, \mathrm{Cu}, \mathrm{Pb})$ or high $(\mathrm{Ag})$ levels of metals comparing to the marine background or to UCC levels and the EF values showed a significant to moderate enrichment especially for $\mathrm{Ag}, \mathrm{Pb}, \mathrm{Cd}, \mathrm{Cu}$ and $\mathrm{Hg}$ in order. The principal component analysis PCA showed that the contaminants elements were associated to terrigenous elements inputs and a contamination gradient from D0 to D2. This pollution or inputs of contaminants were due to numerous anthropogenic activities in the area such as the discharge of industrial effluents and non-treated wastewater and the high maritime activities. Moreover, this maritime activity contributed to the resuspension of sediments, which modified and altered the diagenetic sequences. Selective extraction (acid, ascorbate and alkaline) indicated the carrier phases of the studied trace elements (organic matter and $\mathrm{Mn} / \mathrm{Fe}$ oxides) and evidenced the mobility of trace elements in the sediments. More specifically, the main diagenetic processes influencing the remobilization of elements in pore waters were $\mathrm{Mn} / \mathrm{Fe}$ (oxy)hydroxide reduction and this was proven with the release of dissolved trace 

Beirut River appeared to be a necessity to identify more properly the source of inputs of the studied trace metals.

\section{Acknowledgment}

The National Council for Scientific Research - CNRS/L (Lebanon) financially funds this work. The authors and co-authors thank the scientific team of CANA scientific vessels for diving and samples collection during this study. Dr. BORSCHNECK Daniel from CEREGE - France for the mineralogy measurement and Marie-Claire Perello from Bordeaux University - France for granulometry measurement.

\section{Conflict of interest}

There are no conflicts to declare.

\section{References}

Abi-ghanem, C., 2008. "Spéciation” des trois éléments trace mercure, plomb et cadmium dans les sédiments des zones côtière libanaises. Institut des Sciences et Industries du Vivant et de l'Environnement.

Abi-Ghanem, C., Chiffoleau, J.F., Bermond, A., Nakhlé, K., Khalaf, G., Borschneck, D., Cossa, D., 2009. Lead and its isotopes in the sediment of three sites on the Lebanese coast: Identification of contamination sources and mobility. Appl. Geochemistry 24, 1990-1999. https://doi.org/10.1016/j.apgeochem.2009.07.012

Achard, R., 2013. Dynamique des contaminants inorganiques dans les sédiments de dragage; Rôle spécifique de la matière organique. Université du Sud Toulon Var.

Achterberg, E.P., Van Den Berg, C.M.G., Boussemart, M., Davison, W., 1997. Speciation and cycling of trace metals in Esthwaite Water: A productive English lake with seasonal deep-water anoxia. Geochim. Cosmochim. Acta 61, 5233-5253. https://doi.org/10.1016/S0016-7037(97)00316-5

Adamo, P., Arienzo, M., Imperato, M., Naimo, D., Nardi, G., Stanzione, D., 2005. Distribution and partition of heavy metals in surface and sub-surface sediments of Naples city port. Chemosphere 61, 800-809. https://doi.org/10.1016/j.chemosphere.2005.04.001

Algeo, T.J., Maynard, J.B., 2004. Trace-element behavior and redox facies in core shales of Upper Pennsylvanian Kansas-type cyclothems. Chem. Geol. 206, 289-318. https://doi.org/10.1016/j.chemgeo.2003.12.009

Álvarez-Iglesias, P., Rubio, B., Pérez-Arlucea, M., 2006. Reliability of subtidal sediments as 
"geochemical recorders" of pollution input: San Simón Bay (Ría de Vigo, NW Spain). Estuar. Coast. Shelf Sci. 70, 507-521. https://doi.org/10.1016/j.ecss.2006.07.001

Anschutz, P., Chaillou, G., Lecroart, P., 2007. Phosphorus diagenesis in sediment of the Thau Lagoon. Estuar. Coast. Shelf Sci. 72, 447-456. https://doi.org/10.1016/j.ecss.2006.11.012

Audry, S., Blanc, G., Schäfer, J., Chaillou, G., Robert, S., 2006. Early diagenesis of trace metals (Cd, Cu, $\mathrm{Co}, \mathrm{Ni}, \mathrm{U}, \mathrm{Mo}$, and $\mathrm{V}$ ) in the freshwater reaches of a macrotidal estuary. Geochim. Cosmochim. Acta 70, 2264-2282. https://doi.org/10.1016/j.gca.2006.02.001

Blott S.J., Pye K., 2001. GRADISTAT: a grain size distribution and statistics package for the analysis of unconsolidated sediments. Earth Surf. Process. Landforms 26, 1237-1248.

Briant, N., Bancon-Montigny, C., Elbaz-Poulichet, F., Freydier, R., Delpoux, S., Cossa, D., 2013. Trace elements in the sediments of a large Mediterranean marina (Port Camargue, France): Levels and contamination history. Mar. Pollut. Bull. 73, 78-85. https://doi.org/10.1016/j.marpolbul.2013.05.038

Burdige, D.J., Komada, T., 2011. Anaerobic oxidation of methane and the stoichiometry of remineralization processes in continental margin sediments. Limnol. Oceanogr. 56, 1781-1796. https://doi.org/10.4319/lo.2011.56.5.1781

Burgos, M., Ortega, T., Bohórquez, J., Corzo, A., Rabouille, C., Forja, J.M., 2018. Seasonal variation of early diagenesis and greenhouse gas production in coastal sediments of Cadiz Bay: Influence of anthropogenic activities. Estuar. Coast. Shelf Sci. 200, 99-115. https://doi.org/10.1016/j.ecss.2017.10.016

Burton, E.D., Phillips, I.R., Hawker, D.W., 2005. Trace metal distribution and enrichment in benthic, estuarine sediments: Southport Broadwater, Australia. Environ. Geochem. Health 27, 369-383. https://doi.org/10.1007/s10653-004-7086-x

Canavan, R.W., Slomp, C.P., Jourabchi, P., Van Cappellen, P., Laverman, A.M., van den Berg, G.A., 2006. Organic matter mineralization in sediment of a coastal freshwater lake and response to salinization. Geochim. Cosmochim. Acta 70, 2836-2855. https://doi.org/10.1016/j.gca.2006.03.012

Canfield, D.E., Thamdrup, B., Hansen, J.W., 1993. The anaerobic degradation of organic matter in Danish coastal sediments: Iron reduction, manganese reduction, and sulfate reduction. Geochim. Cosmochim. Acta 57, 3867-3883. https://doi.org/10.1016/0016-7037(93)90340-3

Cauwet, G., 1987. Influence of sedimentological features on the distribution of trace metals in marine sediments. Mar. Chem. 22, 221-234. https://doi.org/10.1016/0304-4203(87)90010-7

Chaillou, G., Schäfer, J., Anschutz, P., Lavaux, G., Blanc, G., 2003. The behaviour of arsenic in muddy sediments of the Bay of Biscay (France). Geochim. Cosmochim. Acta 67, 2993-3003. https://doi.org/10.1016/S0016-7037(03)00204-7

Chester, R., 1990. Marine Geochemistry 698.

Cossa, D., Buscail, R., Puig, P., Chiffoleau, J.F., Radakovitch, O., Jeanty, G., Heussner, S., 2014. Origin and accumulation of trace elements in sediments of the northwestern Mediterranean margin. Chem. Geol. 380, 61-73. https://doi.org/10.1016/j.chemgeo.2014.04.015

Couture, R., Gobeil, C., Tessier, A., 2010. Arsenic , iron and sulfur co-diagenesis in lake sediments. Geochim. Cosmochim. Acta 74, 1238-1255. https://doi.org/10.1016/j.gca.2009.11.028 
Dang, D.H., Lenoble, V., Durrieu, G., Omanović, D., Mullot, J.U., Mounier, S., Garnier, C., 2015. Seasonal variations of coastal sedimentary trace metals cycling: Insight on the effect of manganese and iron (oxy)hydroxides, sulphide and organic matter. Mar. Pollut. Bull. 92, 113-124. https://doi.org/10.1016/j.marpolbul.2014.12.048

Dang, D.H., Tessier, E., Lenoble, V., Durrieu, G., Omanović, D., Mullot, J.U., Pfeifer, H.R., Mounier, S., Garnier, C., 2014. Key parameters controlling arsenic dynamics in coastal sediments: An analytical and modeling approach. Mar. Chem. 161, 34-46. https://doi.org/10.1016/j.marchem.2014.02.005

Elbaz-Poulichet, F., 2005. River Inputs of Metals and Arsenic, in: The Mediterranean Sea. pp. 567-578. https://doi.org/10.1007/b107148

Froelich, P.N., Klinkhammer, G.P., Bender, M.L., Luedtke, N.A., Heath, G.R., Cullen, D., Dauphin, P., Hammond, D., Hartman, B., Maynard, V., 1979. Early oxidation of organic matter in pelagic sediments of the eastern equatorial Atlantic: suboxic diagenesis. Geochim. Cosmochim. Acta 43, 1075-1090. https://doi.org/10.1016/0016-7037(79)90095-4

Gobeil, C., Silverberg, N., 1989. Early diagenesis of lead in Laurentian Trough sediments. Geochim. Cosmochim. Acta 53, 1889-1895. https://doi.org/10.1016/0016-7037(89)90310-4

Haese, R.R., Schramm, J., Van Rutgers Der Loeff, M.M., Schulz, H.D., 2000. A comparative study of iron and manganese diagenesis in continental slope and deep sea basin sediments off Uruguay (SW Atlantic). Int. J. Earth Sci. 88, 619-629. https://doi.org/10.1007/s005310050292

Heggie, D., Lewis, T., 1984. Cobalt in pore waters of marine sediments. Nat. Publ. Gr. 311, 453-454. https://doi.org/10.1038/309126a0

Ho, H.H., Swennen, R., Cappuyns, V., Vassilieva, E., Van Gerven, T., Tran, T. Van, 2012. Potential release of selected trace elements ( $\mathrm{As}, \mathrm{Cd}, \mathrm{Cu}, \mathrm{Mn}, \mathrm{Pb}$ and $\mathrm{Zn}$ ) from sediments in Cam River-mouth (Vietnam) under influence of pH and oxidation. Sci. Total Environ. 435-436, 487-498. https://doi.org/10.1016/j.scitotenv.2012.07.048

Hyacinthe, C., Anschutz, P., Carbonel, P., Jouanneau, J.M., Jorissen, F.J., 2001. Early diagenetic processes in the muddy sediments of the bay of biscay. Mar. Geol. 177, 111-128. https://doi.org/10.1016/S0025-3227(01)00127-X

Kontas, A., 2008. Trace metals (Cu, Mn, Ni, Zn, Fe) contamination in marine sediment and zooplankton samples from Izmir Bay. (Aegean Sea, Turkey). Water. Air. Soil Pollut. 188, 323-333. https://doi.org/10.1007/s11270-007-9547-1

Larrose, A., Coynel, A., Schäfer, J., Blanc, G., Massé, L., Maneux, E., 2010. Assessing the current state of the Gironde Estuary by mapping priority contaminant distribution and risk potential in surface sediment. Appl. Geochemistry 25, 1912-1923. https://doi.org/10.1016/j.apgeochem.2010.10.007

Leleyter, L., Baraud, F., 2005. Évaluation de la mobilité des métaux dans les sédiments fluviaux du bassin de la Vire (Normandie, France) par extractions simples ou séquentielles. Comptes Rendus - Geosci. 337, 571-579. https://doi.org/10.1016/j.crte.2005.01.001

Lesven, L., Gao, Y., Billon, G., Leermakers, M., Ouddane, B., Fischer, J.C., Baeyens, W., 2008. Early diagenetic processes aspects controlling the mobility of dissolved trace metals in three riverine sediment columns. Sci. Total Environ. 407, 447-459. https://doi.org/10.1016/j.scitotenv.2008.08.033 
Lu, X., Zhang, Y., Liu, H., Xing, M., Shao, X., Zhao, F., Li, X., Liu, Q., Yu, D., Yuan, X., Yuan, M., 2014. Influence of early diagenesis on the vertical distribution of metal forms in sediments of Bohai Bay, China. Mar. Pollut. Bull. 88, 155-161. https://doi.org/10.1016/j.marpolbul.2014.09.011

Maatouk, E., 2015. Caractérisation des eaux usées au Liban : impact sur le fonctionnement des stations d'épuration. Université Paris-Est.

Mahu, E., Nyarko, E., Hulme, S., Coale, K.H., 2015. Distribution and enrichment of trace metals in marine sediments from the Eastern Equatorial Atlantic, off the Coast of Ghana in the Gulf of Guinea. Mar. Pollut. Bull. 98, 301-307. https://doi.org/10.1016/j.marpolbul.2015.06.044

Nakhle, K., 2004. Le mercure, le cadmium et le plomb dans les eaux littorales libanaises: apports et suivi au moyen de bioindicateurs quantitatifs (eponges, bivalves et gasteropodes). Université Paris 7.

Nassif, N., 2010. Studying Heavy Metals in Sediments Layers along Selected Sites on the Lebanese Coast. J. Water Resour. Prot. 02, 48-60. https://doi.org/10.4236/jwarp.2010.21006

Pan, K., Wang, W.X., 2012. Trace metal contamination in estuarine and coastal environments in China. Sci. Total Environ. 421-422, 3-16. https://doi.org/10.1016/j.scitotenv.2011.03.013

Peng, J. feng, Song, Y. hui, Yuan, P., Cui, X. yu, Qiu, G. lei, 2009. The remediation of heavy metals contaminated sediment. J. Hazard. Mater. 161, 633-640. https://doi.org/10.1016/j.jhazmat.2008.04.061

Prajith, A., Rao, V.P., Chakraborty, P., 2016. Distribution, provenance and early diagenesis of major and trace metals in sediment cores from the Mandovi estuary, western India. Estuar. Coast. Shelf Sci. 170, 173-185. https://doi.org/10.1016/j.ecss.2016.01.014

Qian, Y., Zhang, W., Yu, L., Feng, H., 2015. Metal Pollution in Coastal Sediments. Curr. Pollut. Reports 1, 203-219. https://doi.org/10.1007/s40726-015-0018-9

Rigaud, S., 2011. DYNAMIQUE ET BIODISPONIBILITE DES ELEMENTS TRACES METALLIQUES DANS LES SEDIMENTS DE L’ETANG DE BERRE. Université Paul Cezanne.

Rigaud, S., Radakovitch, O., Couture, R.M., Deflandre, B., Cossa, D., Garnier, C., Garnier, J.M., 2013. Mobility and fluxes of trace elements and nutrients at the sediment-water interface of a lagoon under contrasting water column oxygenation conditions. Appl. Geochemistry 31, 35-51. https://doi.org/10.1016/j.apgeochem.2012.12.003

Scholz, F., Neumann, T., 2007. Trace element diagenesis in pyrite-rich sediments of the Achterwasser lagoon, SW Baltic Sea. Mar. Chem. 107, 516-532. https://doi.org/10.1016/j.marchem.2007.08.005

Shaw, T.J., Gieskes, J.M., Jahnke, R.A., 1990. Early diagenesis in differing depositional environments: The response of transition metals in pore water. Geochim. Cosmochim. Acta 54, 1233-1246. https://doi.org/10.1016/0016-7037(90)90149-F

Singh, K.P., Mohan, D., Singh, V.K., Malik, A., 2005. Studies on distribution and fractionation of heavy metals in Gomti river sediments - A tributary of the Ganges, India. J. Hydrol. 312, 14-27. https://doi.org/10.1016/j.jhydrol.2005.01.021

Sutherland, A.R., 2000. Bed sediment-associated trace metals in an urban stream, Oahu, Hawaii. Environ. Geol. 39, 611-627. https://doi.org/10.1007/s002540050473

Tankere-Muller, S., Zhang, H., Davison, W., Finke, N., Larsen, O., Stahl, H., Glud, R.N., 2007. Fine 
scale remobilisation of $\mathrm{Fe}, \mathrm{Mn}, \mathrm{Co}, \mathrm{Ni}, \mathrm{Cu}$ and $\mathrm{Cd}$ in contaminated marine sediment. Mar. Chem. 106, 192-207. https://doi.org/10.1016/j.marchem.2006.04.005

Tessier, E., Garnier, C., Mullot, J.U., Lenoble, V., Arnaud, M., Raynaud, M., Mounier, S., 2011. Study of the spatial and historical distribution of sediment inorganic contamination in the Toulon bay (France). Mar. Pollut. Bull. 62, 2075-2086. https://doi.org/10.1016/j.marpolbul.2011.07.022

Ujević, I., Odžak, N., Barić, A., 2000. Trace metal accumulation in different grain size fractions of the sediments from a semi-enclosed bay heavily contaminated by urban and industrial wastewaters. Water Res. 34, 3055-3061. https://doi.org/10.1016/S0043-1354(99)00376-0

Wang, Y., Ling, M., Liu, R., Yu, P., Tang, A., Luo, X., Ma, Q., 2017. Distribution and source identification of trace metals in the sediment of Yellow River Estuary and the adjacent Laizhou Bay. Phys. Chem. Earth 97, 62-70. https://doi.org/10.1016/j.pce.2017.02.002

Wedepohl, K.H., 1995. The composition of the continental crust. Geochim. Cosmochim. Acta 59, $1217-$ 1232. https://doi.org/10.1016/0016-7037(95)00038-2

Zhang, H.A.O., Van Den Berg, C.M.G., Wollast, R., 1990. The Determination of Interactions of Cobalt ( II ) with Organic Compounds in Seawater using Cathodic Stripping Voltammetry. Mar. Chem. 28, 285-300. 